\title{
Metabolic Signatures of Cryptosporidium paroum-Infected HCT-8 Cells and Impact of Selected Metabolic Inhibitors on C. parvum Infection under Physioxia and Hyperoxia
}

\author{
Juan Vélez ${ }^{1,2, *} \mathbb{C}$, Zahady Velasquez ${ }^{1}{ }^{\circledR}$, Liliana M. R. Silva ${ }^{1}\left(\mathbb{D}\right.$, Ulrich Gärtner $^{3}$, Klaus Failing ${ }^{4}$, \\ Arwid Daugschies ${ }^{5}$, Sybille Mazurek ${ }^{2}$, Carlos Hermosilla ${ }^{1}\left(\mathbb{D}\right.$ and Anja Taubert ${ }^{1}$ \\ 1 Biomedical Research Center Seltersberg, Institute of Parasitology, Justus Liebig University-Giessen, \\ Schubert Str. 81, 35392 Giessen, Germany; zahady.velasquez@vetmed.uni-giessen.de (Z.V.); \\ liliana.silva@vetmed.uni-giessen.de (L.M.R.S.); carlos.r.hermosilla@vetmed.uni-giessen.de (C.H.); \\ anja.tauber@@vetmed.uni-giessen.de (A.T.) \\ 2 Institute of Veterinary Physiology and Biochemistry, Justus Liebig University-Giessen, Frankfurter Str. 100, \\ 35392 Giessen, Germany; sybille.mazurek@vetmed.uni-giessen.de \\ 3 Institute of Anatomy and Cell Biology, Justus Liebig University-Giessen, Aulweg 123, 35392 Giessen, \\ Germany; ulrich.gaertner@anatomie.med.uni-giessen.de \\ 4 Unit for Biomathematics and Data Processing, Justus Liebig University-Giessen, Frankfurter Str. 95, \\ 35392 Giessen, Germany; klaus.failing@vetmed.uni-giessen.de \\ 5 Institute of Parasitology, University of Leipzig, An den Tierkliniken 35, 04103 Leipzig, Germany; \\ daugschies@vetmed.uni-leipzig.de \\ * Correspondence: juan.velez@vetmed.uni-giessen.de
}

check for

updates

Citation: Vélez, J.; Velasquez, Z.; Silva, L.M.R.; Gärtner, U.; Failing, K.; Daugschies, A.; Mazurek, S.; Hermosilla, C.; Taubert, A. Metabolic Signatures of Cryptosporidium parvum-Infected HCT-8 Cells and Impact of Selected Metabolic Inhibitors on C. paroum Infection under Physioxia and Hyperoxia. Biology 2021, 10, 60. https://doi.org/ 10.3390/biology10010060

Received: 5 November 2020 Accepted: 12 January 2021 Published: 15 January 2021

Publisher's Note: MDPI stays neutral with regard to jurisdictional clai$\mathrm{ms}$ in published maps and institutional affiliations.

Copyright: (C) 2021 by the authors. Licensee MDPI, Basel, Switzerland. This article is an open access article distributed under the terms and conditions of the Creative Commons Attribution (CC BY) license (https:// creativecommons.org/licenses/by/ $4.0 /)$
Simple Summary: Cryptosporidium parvum is one of the causal agents of cryptosporidiosis. This waterborne disease is responsible for around one million human deaths every year and the only approved anti-cryptosporidial drug for humans, i.e., nitazoxanide, lacks efficacy in immunocompromised patients. We here present, to the best of our knowledge, the first analyses of $C$. parvum impact on the metabolism of its host-cells under physiological oxygen conditions. Moreover, based on the here presented metabolic evidence, we blocked specific metabolic pathways in order to find new anti-cryptosporidial targets. Our findings besides confirming glycolysis as anti-cryptosporidial target prove glutaminolysis and lactate release as necessary for parasite replication.

Abstract: Cryptosporidium parvum is an apicomplexan zoonotic parasite recognized as the second leading-cause of diarrhoea-induced mortality in children. In contrast to other apicomplexans, C. parvum has minimalistic metabolic capacities which are almost exclusively based on glycolysis. Consequently, C. parvum is highly dependent on its host cell metabolism. In vivo (within the intestine) infected epithelial host cells are typically exposed to low oxygen pressure $\left(1-11 \% \mathrm{O}_{2}\right.$ termed physioxia). Here, we comparatively analyzed the metabolic signatures of C. parvum-infected HCT- 8 cells cultured under both, hyperoxia $\left(21 \% \mathrm{O}_{2}\right)$, representing the standard oxygen condition used in most experimental settings, and physioxia $\left(5 \% \mathrm{O}_{2}\right)$, to be closer to the in vivo situation. The most pronounced effect of $C$. parvum infection on host cell metabolism was, on one side, an increase in glucose and glutamine uptake, and on the other side, an increase in lactate release. When cultured in a glutamine-deficient medium, C. parvum infection led to a massive increase in glucose consumption and lactate production. Together, these results point to the important role of both glycolysis and glutaminolysis during C. paroum intracellular replication. Referring to obtained metabolic signatures, we targeted glycolysis as well as glutaminolysis in C. parvum-infected host cells by using the inhibitors lonidamine [inhibitor of hexokinase, mitochondrial carrier protein (MCP) and monocarboxylate transporters (MCT) 1, 2, 4], galloflavin (lactate dehydrogenase inhibitor), syrosingopine (MCT1and MCT4 inhibitor) and compound 968 (glutaminase inhibitor) under hyperoxic and physioxic conditions. In line with metabolic signatures, all inhibitors significantly reduced parasite replication under both oxygen conditions, thereby proving both energy-related metabolic pathways, glycolysis and glutaminolysis, but also lactate export mechanisms via MCTs as pivotal for C. parvum under in vivo physioxic conditions of mammals. 
Keywords: Cryptosporidium parvum; cryptosporidiosis; hyperoxia; physioxia; glycolysis; glutaminolysis

\section{Introduction}

Cryptosporidium parvum is one of the most important causal agents of human and animal cryptosporidiosis [1-5]. This zoonotic parasite (subphylum Apicomplexa) is considered the second-leading aetiology of diarrhoea-related mortality in children $[4,6,7]$, and responsible for almost a million human deaths each year [8,9]. Moreover, the only approved drug in humans against cryptosporidiosis, i.e., nitazoxanide, is neither effective in affected children nor in patients with impaired immune systems [3,10-12]. Therefore, novel effective anti-cryptosporidial therapies are urgently needed, and cryptosporidiosis still represents a challenge for public health worldwide.

C. parvum is a fast-replicating obligate intracellular protozoan with minimalistic metabolic capabilities as a result of a reductive evolution process. This is clearly reflected in its minute genome, merely comprising $9.1 \mathrm{Mb}$ in eight chromosomes compared to $23 \mathrm{Mb}$ in 14-chromosomes of Plasmodium falciparum [13] or other closely related apicomplexans (e.g., Eimeria, Toxoplasma, Neospora, Sarcocystis). Consequently, C. paroum streamlined metabolic repertoire lacks tricarboxylic acid cycle, oxidative phosphorylation, de novo pyrimidine, amino acid and cholesterol biosynthesis thereby mainly relying on glycolysis for energy production [13-18]. Likewise, C. parvum possesses an extensive pool of genes encoding for families of putative sugar and amino acid transporters $[13,14]$.

Interestingly, Cryptosporidium spp. have emerged from a gregarines' common ancestor which shows a distinct primitive nutritional behaviour known as myzocytosis or "cellular vampirism" by using a feeder organelle for piercing prey cell membranes and sucking out captured nutrients [15,19-22]. In fact, such a predatory strategy could represent the starting point in the transition to a parasitic lifestyle in the earliest apicomplexan ancestors as previously postulated $[15,21,22]$. Reminiscences of such predatory past are the epicellular, i.e., intracellular but extracytoplasmatic parasite localization, and the unique feeder organelle of Cryptosporidium. Successful myzocytotic feeding behaviour is also reported for closely related dinoflagellates and archigregarines [21,22]. Thus, Cryptosporidium spp. attachment and feeding behaviour furnish these protozoans to scavenge host cell nutrients to support their fast and energy-demanding intracellular replication.

Referring to metabolic C. parvum-host cell-interactions, gene expression-based evidences showed a down-regulation of host-parasite homologous genes in host glycolysis/gluconeogenesis pathways (e.g., phosphofructokinase, aldolase, GAPDH, among others) while host-exclusive genes were upregulated, thereby suggesting a parasite-derived direct competition for metabolic substrates [23]. Gas-chromatography-mass spectrometry (GC-MS)-based studies revealed qualitative and quantitative differences in the faecal metabolite profile of infected and non-infected humans [24] as well as infected and control mice [25]. Interestingly, such faecal metabolite profiles revealed significant higher metabolite concentrations in human infected samples while murine infected samples showed significant lower metabolite concentrations, pointing out that differences in the metabolic impact depend on the host. More recently, a ${ }^{1} \mathrm{H}$-nuclear magnetic resonance (NMR)-based study confirmed differences in host cell metabolism of Cryptosporidium-infected cells both in vitro (COLO-680N cell line) as well as in vivo (murine ileum) [26]. However, increased lactate levels were detected in both COLO-680N and murine ileum [26]. The lactate may derive from increased glucose or amino acid degradation, i.e., glutamine, in C. parvuminfected host cells. Several genomic and biochemical evidences confirmed the dependence of Cryptosporidium on glycolysis as main energy source $[8,13,14,17,27]$. Likewise, different studies demonstrated that pharmacological blockage of glycolysis inhibits parasite replication [27-30], thereby suggesting this metabolic pathway as a promising anti-cryptosporidial target. 
Like Cryptosporidium, several other apicomplexan parasites, such as Toxoplasma gondii, showed glucose-related growth dependence [31-33]. Of note, some of these parasites also revealed the capability to compensate low glucose availability by increased glutamine uptake [31,32]. So far, a similar metabolic plasticity has not been described for C. parvum and - to the best of our knowledge-there are currently no studies in literature reporting glutaminolysis as a potential anti-cryptosporidial target.

Overall, zoonotic-relevant C. parvum is known as a microaerophilic/anaerobic parasite $[22,34,35]$ which naturally resides in the small intestinal epithelium of various mammal species, including humans [36,37]. Of note, the human intestinal epithelium represents one of the largest body organ surfaces and constitutes $40 \mathrm{~m}^{2}$ of interface/interaction area with the external environment and commensal and pathogenic organisms [38], rendering this unique organ into a very particular environment with its own special physiological conditions. Thus, oxygen delivery and consumption in the intestine generates a unique sub-micromolar oxygen partial pressure $\left(\mathrm{pO}_{2}\right)$, known as "tissue normoxia" or "physioxia" [39,40]. The consideration of inherent physioxic conditions has gained great importance, especially since several studies proved the pivotal role of oxygen conditions on metabolism at the cellular level [41,42]. Obviously, metabolic reactions strongly depend on current $\mathrm{O}_{2}$ conditions. Thus, oxidative phosphorylation is the main energy-regenerating process at high oxygen supply while glycolysis is the main cellular energy source under hypoxic conditions. Besides glycolysis, glutaminolysis represents another important energy source, especially in fast proliferating cells, such as intestinal epithelial cells and tumor cells [43-45].

Considering the necessity to evaluate the metabolic impact of $C$. parvum infections at more realistic micromolar oxygen conditions to better simulate the intestinal in vivo situation, we here analyzed the influence of $C$. paroum on host cellular glycolytic and glutaminolytic functions under both physioxic (5\%) and hyperoxic $(21 \%) \mathrm{O}_{2}$ concentrations. Based on these results we studied efficacies of selected metabolic inhibitors on parasite infection rates under physioxia- and hyperoxia conditions in vitro.

\section{Materials and Methods}

\subsection{Host Cell Culture}

Permanent HCT-8 cells (ATCC-CCL-244, LGC Standars) were maintained at $37^{\circ} \mathrm{C}$ and $5 \% \mathrm{CO}_{2}$ using sterile RPMI 1640 cell culture medium (R0883, Sigma-Aldrich, Darmstadt, Germany) supplemented with $0.3 \mathrm{~g} / \mathrm{L}$ L-glutamine (Sigma-Aldrich, Darmstadt, Germany), 10\% fetal bovine serum (FBS; S0115, Biochrom AG, Berlin, Germany), 100 UI penicillin and $0.1 \mathrm{mg}$ streptomycin $/ \mathrm{mL}$ (both Sigma-Aldrich).

HCT-8 cells were seeded at a density of $1 \times 10^{5}$ cells / well into 24-well plastic tissue plates (Eppendorf, Hamburg, Germany) previously treated with $40 \mu \mathrm{g} / \mathrm{mL}$ fibronectin (F1141, Sigma-Aldrich, Darmstadt, Germany). Cells were grown under two different oxygen concentrations, $5 \%$ and $21 \% \mathrm{O}_{2}$, thereby simulating both physioxic conditions of intestine in vivo $[17,40]$ and hyperoxic ones, applied in most $C$. parvum-related studies. Physioxic cultures were performed at $5 \% \mathrm{O}_{2}$ in a physiological cell culture workstation (InvivO ${ }_{2}^{\circledR} 400$, Ruskinn, Vienna, Austria), while hyperoxic cultures $\left(21 \% \mathrm{O}_{2}\right)$ used a standardized incubator (Heracell 240i, Thermo Scientific, Langenselbold, Germany). Cell culture medium for physioxic conditions was placed into the workstation for at least $12 \mathrm{~h}$ prior to experimentation and shaken manually on a regular basis to allow oxygen equilibration as reported elsewhere [46]. Cell medium in both experimental settings was changed every two days.

\subsection{Parasites}

Cryptosporidium parvum oocysts were obtained from experimentally infected calves kept at the large animal stable facility of the Institute of Parasitology, Faculty of Veterinary Medicine, University of Leipzig, Germany, as reported elsewhere [47]. The C. parvum strain used here belonged to the subtype 60-kDa glycoprotein (gp60) IIaA15G2RI, which 
is the most commonly zoonotic subtype to be found in Germany as well as in most other industrialized countries [48-51]. Oocyst stocks were stored in sterile phosphate buffered saline (PBS, pH 7.4) supplemented with $100 \mathrm{UI}$ penicillin and $0.1 \mathrm{mg}$ streptomycin/mL (P4333, Sigma-Aldrich, Darmstadt, Germany) at $4{ }^{\circ} \mathrm{C}$ for a maximum of three months to guarantee infectivity of sporozoites. The above-mentioned oocyst conservation medium was replaced every month as previously described (15).

\subsection{Host Cell Infection}

Sporulated oocysts of $C$. parvum $\left(7 \times 10^{6}\right)$ were pelleted at $5000 \times g$ for 5 min at $4{ }^{\circ} \mathrm{C}$. Thereafter, sporozoite excystation was induced by supplementation of acidified ( $\mathrm{pH}$ 2.0) and sterile pre-warmed $\left(37^{\circ} \mathrm{C}\right) 1 \times$ Hank's Balanced Salt Solution (HBSS, Sigma-Aldrich, Darmstadt, Germany) for $10 \mathrm{~min}$ at $37^{\circ} \mathrm{C}$. Thereafter, free-released C. parvum-sporozoites were pelleted (5000 $\times g$ for $5 \mathrm{~min}$ ) and incubated in non-acidified $1 \times$ HBSS for $10 \mathrm{~min}$ at $37^{\circ} \mathrm{C}$. Following a final centrifugation step $(5000 \times g, 5 \mathrm{~min})$, cells were re-suspended in sterile RPMI 1640 cell culture medium supplement with $0.3 \mathrm{~g} / \mathrm{L}$ L-glutamine, 10\% FBS, 100 UI penicillin and $0.1 \mathrm{mg}$ streptomycin/mL (all Sigma-Aldrich, Darmstadt, Germany). Freshly released and motile sporozoites were added to HCT-8 cell layers for $3 \mathrm{~h}$, thereafter cell layers were washed thrice to remove free sporozoites and oocysts remnants [52], and fresh cell culture medium was added.

\subsection{Live Cell 3D-Holotomography and Scanning Electron Microscopy (SEM) Analyses of C. parvum-Infected Host Cells}

Intracellular development of $C$. parvum-infected HCT- 8 cells was illustrated by live cell 3D-holotomographic microscopy analysis using 3D Cell Explorer $\mathrm{HM}^{\circledR}$ (Nanolive, Lausanne, Switzerland) equipped with $60 \times$ magnification $(\lambda=520 \mathrm{~nm}$, sample exposure $0.2 \mathrm{~mW} / \mathrm{mm}^{2}$ ) and a field depth of $30 \mu \mathrm{m}$. All live 3D-holotomographic images were analyzed using STEVE ${ }^{\circledR}$ software (Nanolive, Lausanne, Switzerland) to obtain a refractive index-based Z-stack and digital staining according to different intracellular organelle-based refractive indices (RI).

SEM-based illustrations were performed on C. parvum-infected and non-infected HCT8 cell layers (negative controls) fixed in $2.5 \%$ glutaraldehyde (Merck) and post-fixed in $1 \%$ osmium tetroxide (Merck). After washing in distilled water and dehydration, samples were dried by $\mathrm{CO}_{2}$-treatment to a critical point and sputtered with gold particles. Samples were analyzed using a scanning electron microscope (Philips XL30 ${ }^{\circledR}$, Dreieich, Germany) at the Institute of Anatomy and Cell Biology, Justus Liebig University Giessen, Germany, as described by Fichtner et al. [53].

\subsection{Vicia Villosa Lectin-Based Detection of C. paroum Infections}

Cell layers were washed thrice in sterile $1 \times$ PBS, fixed in $4 \%$ paraformaldehyde (Merck, $15 \mathrm{~min}$ ) and washed again thrice in $1 \times$ PBS. For permeabilization and blocking, host cells were treated with $0.3 \%$ Triton X-100 (T-8787, Sigma-Aldrich) and 3\% bovine serum albumin (BSA, Sigma-Aldrich) for $1 \mathrm{~h}$, at RT. For parasite detection, biotinylated Vicia villosa-derived lectin (B-1235-2, VVL, 1:2000 dilution, vector laboratories) was added (45 min, RT, dark chamber) to the samples. Thereafter, all samples were washed three times in sterile $1 \times$ PBS. For visualization of host cell nuclei, DNA was stained by adding 3\% BSA-solution containing Hoechst 33258 staining (Sigma-Aldrich, $1 \mu \mathrm{g} / \mathrm{mL} ; 15 \mathrm{~min}$,). To visualize host cell membranes, cells were additionally stained by anti- $\beta$-catenin (13-8400, Invitrogen, 1:500 dilution, $15 \mathrm{~min}$ ). Thereafter, samples were carefully mounted in anti-fading buffer Fluoromont-GTM (Invitrogen), and allowed to dry ( $24 \mathrm{~h}, \mathrm{RT}$, dark chamber). Samples were analyzed with an epifluorescence microscope (IX81, Olympus, $100 \times$ magnification). Two images were obtained with $40 \times$ magnification on each technical replicate $(n=6)$ and merged for intracellular parasite identification and quantification of infection rates using Image $J^{\circledR}$ [National Institute of Health (NIH), Maryland, MD, USA]. 


\subsection{Quantification of Metabolic Conversion Rates in C. parvum-Infected Host Cell Culture Supernatants}

HCT-8 were cultured in 24-well plastic tissue culture plates (Greiner; $n=9$ ) and infected with $C$. parvum sporozoites. Non-infected HCT-8 cell layers were used as negative controls and equally processed as C. parvum-infected ones. Three hours after the infection, the cell culture medium was exchanged (exactly $1 \mathrm{~mL} /$ well) and the cells were further cultivated under physioxic $(5 \%)$ or hyperoxic $(21 \%)$ conditions as described in the relevant experiments. Infection rates were controlled by VVL-based fluorescence assays. At $24 \mathrm{~h}$ p. i., cell culture supernatants were collected and centrifuged $\left(400 \times \mathrm{g}, 10 \mathrm{~min}, 4^{\circ} \mathrm{C}\right)$ to remove cell debris or remnant parasites. Supernatants were collected, aliquoted, immediately frozen in liquid nitrogen and thereafter stored at $-80^{\circ} \mathrm{C}$ until further metabolic analysis.

Additionally, the same above-mentioned procedure was performed with HCT-8 cells cultured in RPMI 1640 cell culture medium containing very low glutamine concentration $(0.02 \mathrm{mM})$.

For estimation of metabolic conversion rates in glutamine-supplemented $(2 \mathrm{mM})$ and glutamine-starved $(0.02 \mathrm{mM})$ HCT-8 cells, frozen medium samples were heated for $15 \mathrm{~min}$ at $80^{\circ} \mathrm{C}$ and subsequently centrifuged at $8000 \times g$ for $10 \mathrm{~min}$. Glucose, pyruvate, lactate, glutamine, glutamate, serine, alanine and aspartate concentrations were determined using a Respons ${ }^{\circledR} 920$ bench top clinical analyzer (DiaSys Diagnostic Systems GmbH, Holzheim, Germany) as described elsewhere [44,45,54-56]. Metabolic conversion rates were calculated in nanomoles per $\left(\mathrm{h} \times 10^{5}\right.$ cells) relative to control medium samples which were incubated in parallel in 24-well plastic tissue culture plates (Greiner) as reference.

\subsection{Host Cell Toxicity Assays}

Host cell toxicity of inhibitors was controlled by both $\mathrm{XTT}^{\circledR}$ metabolic cell proliferation assay (11465015001, Merck, Darmstadt, Germany) and photometric lactate dehydrogenase (LDH) activity measurements in cell supernatants as a measure of LDH release from host cells. For LDH measurements, HCT-8 cells were pre-cultured in 96-well plates (Greiner) for $80 \%$ confluence. Thereafter, the medium was changed and host cells were cultured for $24 \mathrm{~h}$ in presence of respective metabolic inhibitors: [galloflavin (14846, Biomol GmbH, Hamburg, Germany): 200, 400, 800 and $1600 \mu \mathrm{M}$; lonidamine (14640, Biomol GmbH): 75, 150, 300 and $600 \mu \mathrm{M}$, syrosingopine (SML1908, Merck, Darmstadt, Germany) and compound 968 (352010, Merck, Darmstadt, Germany): 2.5, 5, 10, 20, 40, 80, 160 and $320 \mu \mathrm{M}]$. In order to simulate the time period of parasite infection, cells were washed thrice and fresh cell growth medium without inhibitor was added for $3 \mathrm{~h}$. Thereafter, fresh inhibitor-supplemented medium was added and host cells were incubated for additional $21 \mathrm{~h}$. Supernatants were collected and centrifuged $(400 \times g, 5 \mathrm{~min})$, frozen in liquid nitrogen and stored at $-80^{\circ} \mathrm{C}$. LDH activity was measured photometrically according to Bergmeyer 1974 [57], using a Respons ${ }^{\circledR} 920$ bench top clinical analyser (DiaSys Diagnostic Systems $\mathrm{GmbH}$ ). For determination of cell viability, host cells were analysed according to the protocols of XTT ${ }^{\circledR}$ (11465015001, Merck, Darmstadt, Germany, Holzheim, Germany) metabolic proliferation assay. Control cells were incubated with growth medium and $0.1 \%$ dimethyl sulfoxide (317275, DMSO, Merck, Darmstadt, Germany) since this was the highest vehicle concentration used for treatments.

\subsection{Inhibition Assays}

All inhibitors were solved in dimethyl sulfoxide (DMSO, Sigma, Darmstadt, Germany). Control host cell layers were incubated in growth medium containing the DMSO concentration added in the approach with the highest inhibitor concentration.

HCT-8 were seeded on round glass coverslips $(10 \mathrm{~mm}$ diameter, Thermo Fisher Scientific, Braunschweig, Germany) previously pre-coated with $40 \mu \mathrm{g} / \mathrm{mL}$ fibronectin (F1141, Merck, Darmstadt, Germany) and placed in 24-well formats. Three technical replicates were used for each experimental condition. Host cells were grown to $80 \%$ confluence under physioxic- and hyperoxic conditions. $24 \mathrm{~h}$ before infection, respective 
inhibitors were added in fresh medium to host cell monolayers: galloflavin (400 $\mu \mathrm{M})$, lonidamine $(150 \mu \mathrm{M})$, syrosingopine $(10 \mu \mathrm{M})$ and compound $968(10 \mu \mathrm{M})$. In parallel, non-treated C. parvum-infected HCT-8 were co-cultured as infection controls. At $24 \mathrm{~h} \mathrm{p}$. i., cells were fixed and analyzed for infection rates using VVL-based fluorescence assays. For the experimental procedure of parasite infection and pharmacological treatments, refer to Supplementary Figure S1.

\subsection{Analysis of Glycolytic Responses via Seahorse Technology}

For analysis of C. parvum infection- and inhibitor-induced glycolytic responses, the Glycolysis Stress Test Kit ${ }^{\circledR}$ (Agilent, Rathingen, Germany) was applied using a Seahorse XFp extracellular flux analyser ${ }^{\circledR}$ (Agilent, Rathingen, Germany). Therefore, $10^{3}$ HCT-8 cells (triplicates for each experimental condition) were seeded on XFp cell microplates ${ }^{\circledR}$ (Agilent, Rathingen, Germany) for $24 \mathrm{~h}$ ( $\sim 80 \%$ of cell confluence) and treated mimicking the treatment scheme implemented for the inhibitory assays (see Section 2.3 and Figure S1). For inhibitor-induced glycolytic changes on host cells, the following inhibitor concentrations were used: galloflavin $(25,50,100,200,400 \mu \mathrm{M})$, lonidamine $(75,150,300 \mu \mathrm{M})$, syrosingopine $(5,10,20 \mu \mathrm{M})$ and compound $968(5,10,20 \mu \mathrm{M})$. Cells were treated and infected following the same treatment/infection scheme as used for inhibition assays (see Sections 2.3 and 2.8).

Extracellular flux measurements detecting mitochondrial oxygen consumption rates (OCR) and extracellular acidification rates (ECAR) were performed applying a Glycolysis Stress Test Kit ${ }^{\circledR}$ (Agilent, Rathingen, Germany) according to the manufacturer's instructions to evaluate both the cellular glycolytic status and adequate inhibitor doses. Therefore, Seahorse XF 8-well plastic cartridges ${ }^{\circledR}$ (Agilent, Rathingen, Germany) were hydrated with distilled water and placed in an incubator lacking $\mathrm{CO}_{2}$ supply $\left(37^{\circ} \mathrm{C}, 45 \mathrm{~min}\right)$. Before measurements, cell culture medium of all samples was replaced by Dulbecco's Modified Eagle Medium (DMEM)-based medium (Agilent, Rathingen, Germany) supplemented with $2 \mathrm{mM}$ glutamine (Sigma-Aldrich, Darmstadt, Germany). Applying the manufacturer's protocols, quantitative measurements of OCR and ECAR were performed after sequential supplementation of glucose $(10 \mathrm{mM})$, oligomycin $(2.9 \mu \mathrm{M})$ and 2-DG $(60 \mathrm{mM})$ (supplied by the kit) via instrument-own injection ports. Immediately after measurements, cells were fixed and counted for normalization. Glycolysis-related data obtained from Seahorse XF Wave software ${ }^{\circledR}$ (Waldbronn, Germany) were plotted using GraphPad Prism ${ }^{\circledR} 8$ software (San Diego, SD, USA).

In addition, to analyze the effect of C. parvum on glycolysis and glycolytic ATP production in infected host cells, the Seahorse XFp Glycolytic Rate Assay ${ }^{\circledR}$ (Agilent, Rathingen, Germany) was here used applying the same experimental conditions as described above and adding sequentially Rotenone and Antimycin A (Rot/AA) $(0.5 \mu \mathrm{M})$ and 2-deoxy-Dglucose (2-DG) (50 mM) (supplied by the kit). In all cases, three replicates were included. By assuming a $\mathrm{CO}_{2}$ contribution factor of 0.50 [58] and considering that HCT-8 share classical tumour characteristics by depending on glycolysis rather than on mitochondrial oxidative phosphorylation for energy supply [59-61], proton efflux rates (PER) were additionally calculated by means of wave software and plotted using GraphPad Prism ${ }^{\circledR} 8$ software(San Diego, SD, USA).

\subsection{Statistical Analysis}

Overall, data were expressed as mean $\pm \mathrm{SD}$. Evaluation of metabolite conversion rates in supernatants of $C$. parvum-infected and non-infected HCT-8 cells was performed by $t$-test for independent samples applying the module BMDP3D of the statistical program package BMDP/Dynamic, Release 8.1 (Berkeley, USA) [62] on six replicates for each of the four conditions, namely, infected and non-infected under physioxia $\left(5 \% \mathrm{O}_{2}\right)$ and hyperoxia $\left(21 \% \mathrm{O}_{2}\right)$.

Likewise, glycolysis and glycolytic ATP production in C. parvum-infected HCT-8 as well as parasite replication were evaluated by means of $t$-test using GraphPad Prism ${ }^{\circledR}$ 
8 software (San Diego, CA, USA). For evaluation of the inhibitor effect on HCT-8 glycolytic function a one-way (analysis of variance) ANOVA followed by Dunnett's test were performed after confirming normality on data by means of Shapiro-Wilk test using of GraphPad Prism ${ }^{\circledR} 8$ software (San Diego, CA, USA).

In general, for valuation statistical significances a statistical significance level of $\alpha=0.05$ was used. Results with $p$-values lower or equal 0.05 were assessed as statistically significant.

\section{Results}

3.1. C. parvum Infective Stages and Infection Development in HCT-8 Cells Depend on Oxygen Pressure

Live cell 3D-holotomographic microscopy analysis confirmed parasite-related specificity of VVL-based staining in real time (Figure 1a) and, more importantly, in 3D dimensions. By following intracellular development of sporozoites, we identified different $C$. parvum stages, such as trophozoites and meronts and confirmed their specific epicellular localization in host cells (Figure 1b). The lumen-oriented, intracellular but extracytoplasmatic location of $C$. parvum-derived trophozoite was clearly evidenced in HCT-8 infected-host cells (trophozoite, Figure 1b, 3D-digital staining). The difference in the RI of surface and content from analyzed trophozoites is probably dependent on parasitophorous vacuole (PV)-inherent characteristics. Since the PV is one of C. paroum-hallmarks, it is well described that trophozoites always reside inside a PV. The content of here studied trophozoites showed an almost homogenic content, which contrasted with several chambers (up to four, probably meront type II) evidenced in different transversal planes of parasitic stages explored at $48 \mathrm{~h} \mathrm{p}$. i. (Figure 1b, second row). At $48 \mathrm{~h} \mathrm{p}$. i., a C. parvum-merozoite stage was illustrated (Figure 1b, third row) during the attachment and active host cell invasion process. Further, villi-like structures were observed in live infected-host cells (Figure 1a, white arrow).

Moreover, "hole"-like cell membrane damages associated with C. parvum merontand/or gamont-driven ruptures of infected host cells were evidenced by SEM analysis, confirming superficial host epithelial cell features in affected villi in vivo. SEM analyses visualized gradual C. paroum replication resulting in trophozoite-like structures since $4 \mathrm{~h}$ p. i. (Figure 2c) and massively observed at $16 \mathrm{~h} \mathrm{p}$. i. (Figure 2a). As stated above, also $C$. parvum-infected host cells showed hole-like cell membrane damage after meront rupture, (Figure $2 \mathrm{~b}, 16 \mathrm{~h}$ p. i. white arrow), evidencing that some $C$. parvum trophozoites underwent very fast development into mature meront stages and released merozoites in vitro. In addition, villi-like structures were also evidenced by SEM-analysis in C. parvum-infected host cells carrying meront stages (Figure $2 \mathrm{c}, 4$ and $12 \mathrm{~h} \mathrm{p}$. i. black arrows) as previously reported elsewhere [37].

$\mathrm{O}_{2}$-dependent $C$. parvum replication in HCT-8 cells under physioxic $\left(5 \% \mathrm{O}_{2}\right)$ and hyperoxic $\left(21 \% \mathrm{O}_{2}\right)$ in vitro culture conditions was evaluated in at least three experimental series. When applying parasite stages from identical excystation processes on HCT-8 cells propagated under the above mentioned $\mathrm{O}_{2}$ conditions, the lower oxygen disposability ( $5 \%$ $\mathrm{O}_{2}$ ) generally resulted in lower infection rates. In addition, infection rates generally varied with individual excystations. Referring to the different experimental settings, the following infection rates were detected: $46 \pm 21 \%\left(5 \% \mathrm{O}_{2}\right)$ and $75 \pm 10 \%\left(21 \% \mathrm{O}_{2}\right)$ in experiments on measurement of metabolic conversion rates when cells were cultivated in presence of $2 \mathrm{mM}$ glutamine in the medium (Figure 3) and $28 \pm 7 \%\left(5 \% \mathrm{O}_{2}\right)$ and $40 \pm 3 \%\left(21 \% \mathrm{O}_{2}\right)$ when cells were cultivated in glutamine-starved medium ( $0.02 \mathrm{mM}$ glutamine) (Figure 4$)$. $15 / 45 \pm 9 / 6 \%\left(5 \% \mathrm{O}_{2}\right)$ and $17 / 53 \pm 2 / 15 \%\left(21 \% \mathrm{O}_{2}\right)$ in repeated experiments on metabolic blockers in the presence of $2 \mathrm{mM}$ glutamine. 

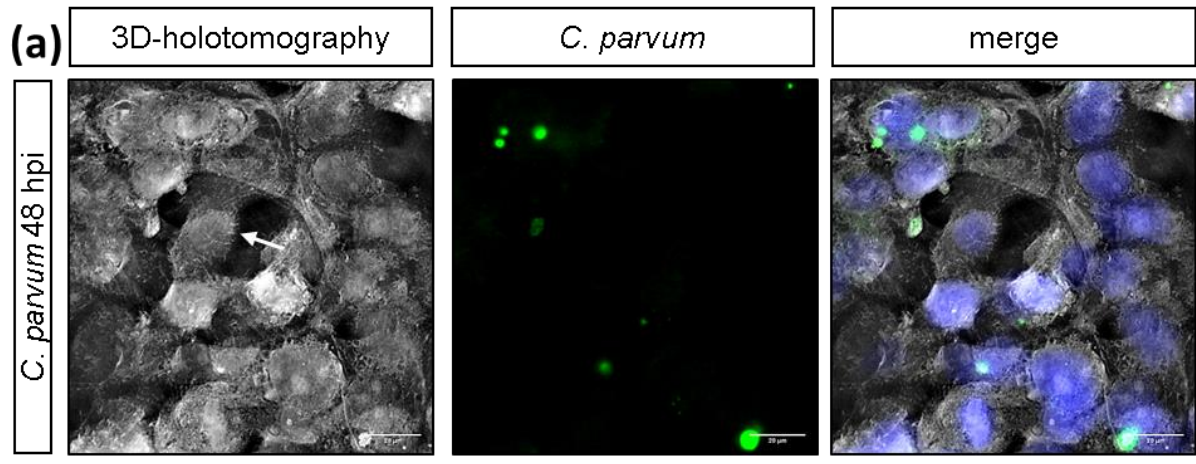

(b) 3D-holotomography

3D-rendering 3 D-digital staining
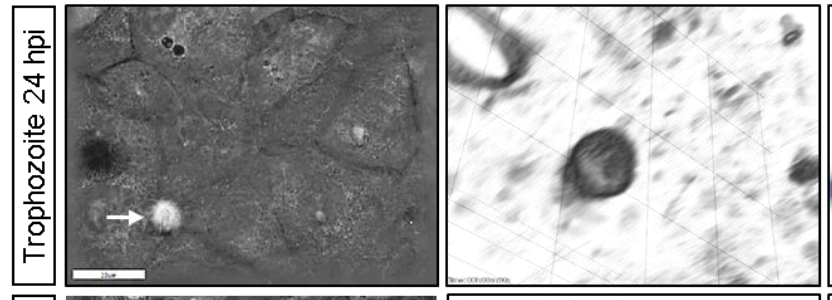

3D-digital staining
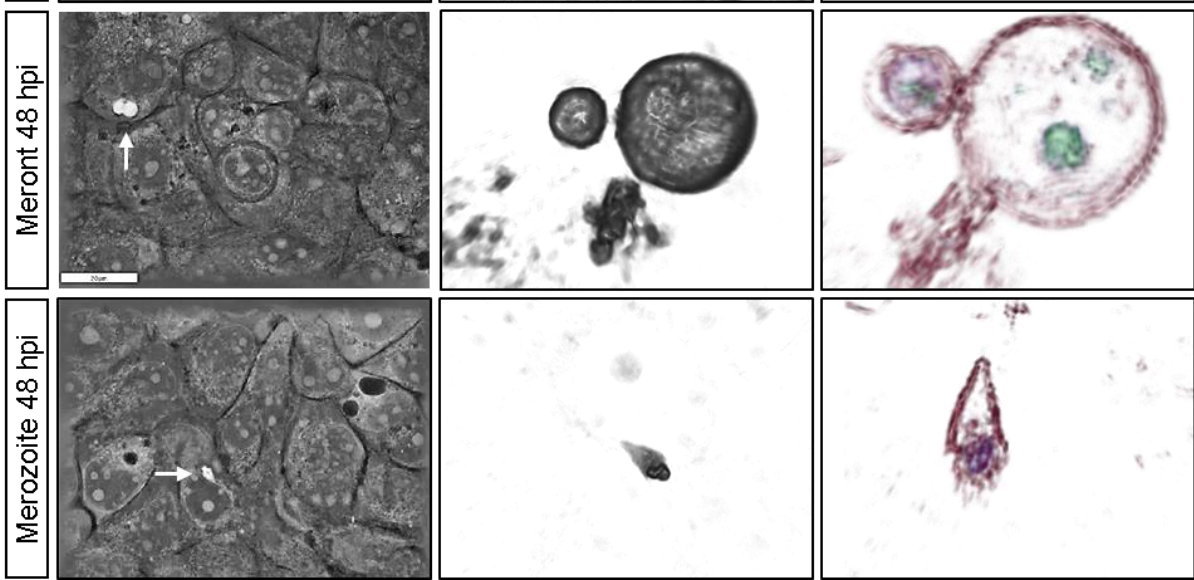

Figure 1. 3D-holotomographic illustration of C. parvum-infected HCT-8. (a) C. parvum-infected HCT- 8 cells were stained by biotinylated VVL and Hoechst 33258 at 24 and $48 \mathrm{~h}$ p. i. $(n=3)$ : (a) 3D-holotomographic images were obtained by using 3D Cell Explorer microscope (Nanolive) at $60 \times$ magnification $\left(\lambda=520 \mathrm{~nm}\right.$, sample exposure $\left.0.2 \mathrm{~mW} / \mathrm{mm}^{2}\right)$ and a depth of field of $30 \mu \mathrm{m}$. (b) Holotomography of C. parvum-infected HCT-8 and identification of trophozoite, meront and merozoite stages (Scale bar $=20 \mu \mathrm{m})$. 
(a)
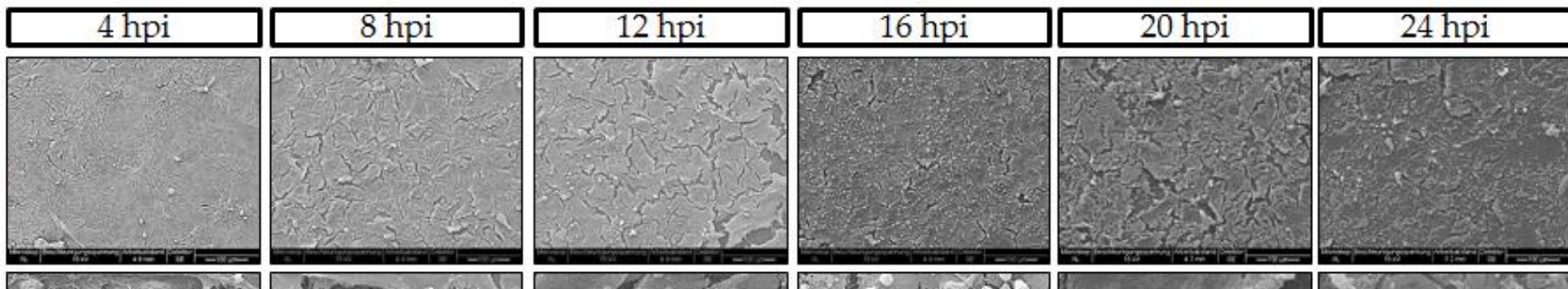

(b)
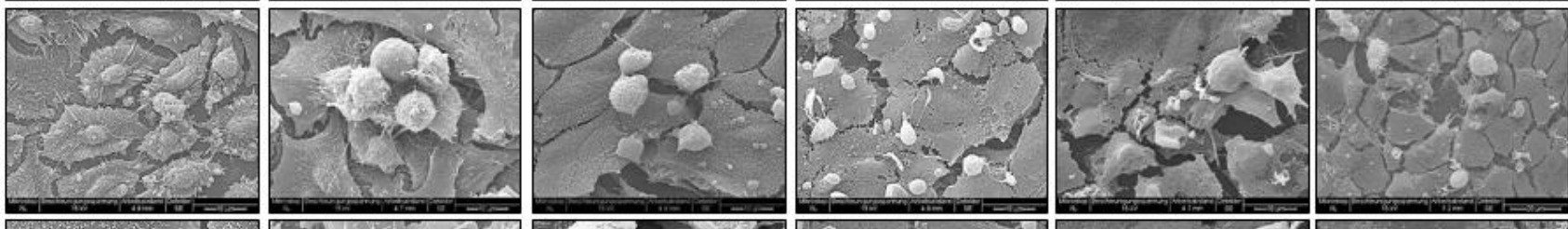

(c)
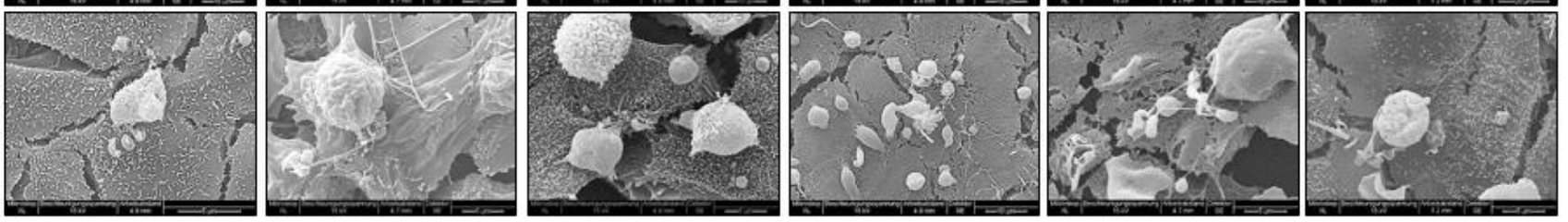

Figure 2. C. parvum development in HCT-8 cells under hyperoxic $\left(21 \% \mathrm{O}_{2}\right)$ conditions $(n=6)$. SEM-based illustration of C. parvum-infected HCT-8 evidenced rapid C. parvum development and infection kinetics: (a) Overviews at different time points post infection (4-24 h p. i.). (b,c) Closer views of parasite stages-host cell interactions, i.e., column at $16 \mathrm{~h}$ p. i. shows meront-infected cells, row $\mathrm{b}$ evidenced hole-like damage on host cell surface induced by merozoites release at the same time point (white arrow). Row c (4 h p. i.) reveals early induction of villi-like structures on surface of infected cells (black arrows).
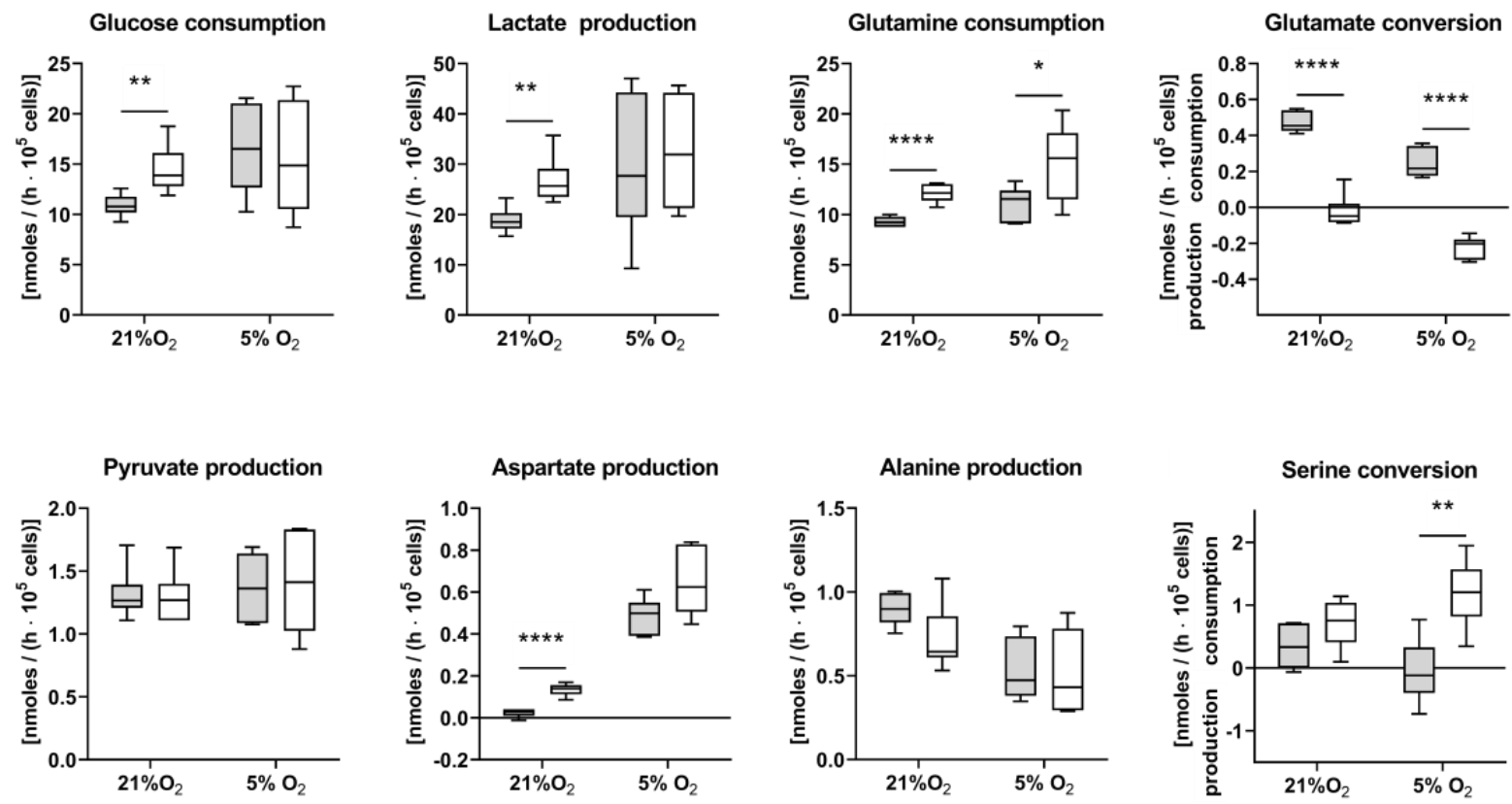

$\square$ Control $\square$ C. parvum

Figure 3. Glucose, lactate, pyruvate, aspartate, glutamine, glutamate, alanine and serine conversion rates in uninfected and C. parvum-infected HCT-8 cultivated in glutamine supplemented medium $(2 \mathrm{mM})$ under hyperoxic $\left(21 \% \mathrm{O}_{2}\right)$ and physioxic $\left(5 \% \mathrm{O}_{2}\right)$ conditions $(n=6$, each group). Metabolite conversion rates were analyzed at $24 \mathrm{~h}$ p. i. in the cultivation supernatants of the cells and presented as interleaved box and whiskers plots with line at median, bars indicating maximum and minimum values. Statistical significance $\left({ }^{*}=p \leq 0.05,{ }^{* *}=p \leq 0.01,{ }^{* * * *}=p \leq 0.0001\right)$ was evaluated by $t$-test for independent samples. 

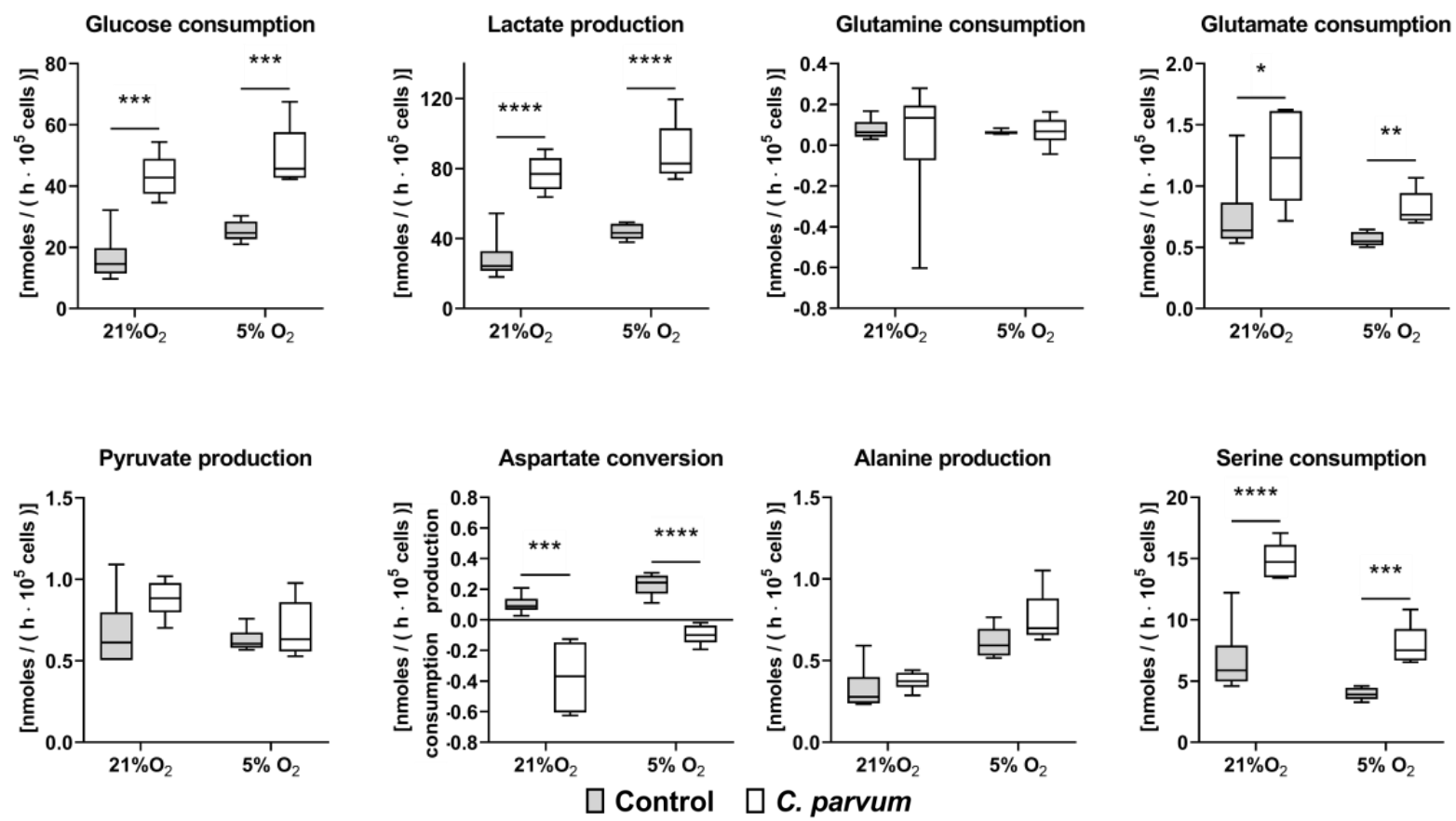

Figure 4. Glucose, lactate, pyruvate, aspartate, glutamine, glutamate, alanine and serine conversion rates in uninfected and C. parvum-infected HCT-8 cultivated in glutamine-starved medium $(0.02 \mathrm{mM})$ at hyperoxia $\left(21 \% \mathrm{O}_{2}\right)$ and physioxia $\left(5 \% \mathrm{O}_{2}\right)(n=6$, each group). In comparison to glutamine-supplemented cultivation conditions the parasite infection rate slightly dropped in glutamine starved medium $\left(21 \% \mathrm{O}_{2}: 40 \pm 3 \% ; 5 \% \mathrm{O}_{2}: 28 \pm 7 \%\right)$. Conversion rates were analysed at $48 \mathrm{~h}$ p. i. in the cell culture supernatants of the cells. Metabolic conversion rates are plotted as interleaved box and whiskers plots showing minimum to maximum values with line at the medians. Statistical significance $\left({ }^{*}=p \leq 0.05,{ }^{* *}=p \leq 0.01\right.$, $\left.{ }^{* * *}=p \leq 0.001, * * * *=p \leq 0.0001\right)$ was determined by $t$-test for independent samples.

\subsection{Metabolic Signatures of C. parvum-Infected HCT-8 Cells Depend on Oxygen and Glutamine Supply}

C. parvum-infected and non-infected HCT-8 cells were cultivated and passaged under hyperoxic $\left(21 \% \mathrm{O}_{2}\right)$ and physioxic $\left(5 \% \mathrm{O}_{2}\right)$ conditions in the presence of $2 \mathrm{mM}$ glutamine $(2 \mathrm{mM}$ glutamine $=$ glutamine-supplemented cells $)$. The metabolic signature of C. parvum-infected host cells was characterized by measuring the conversion rates of selected metabolites in the medium supernatants of infected cells comparing to non-infected controls.

When cultured in the presence of $21 \% \mathrm{O}_{2}$ (hyperoxia) C. parvum infection was associated with a significant increase of glucose consumption, lactate production, glutamine consumption and aspartate production as well as a reversal in glutamate conversion from consumption to production (Figure 3). The consumption of glutamine also significantly increased in the infected cells during hypoxia while the difference in lactate and aspartate production was no longer significant when cultivated in presence of $5 \% \mathrm{O}_{2}$ (physioxia). However, when cultivated in the presence of $5 \% \mathrm{O}_{2}$, there was a change in serine conversion rates from production in non-infected control cells to consumption in C. parvum-infected host cells. During serinolysis, serine is converted to glycerate 2-P and infiltrated into the glycolytic pathway whereby the amino group of serine is transferred to pyruvate with production of alanine. Alternatively, serine can be converted to glycine and cysteine which are precursors for the synthesis of nucleic acid, phospholipids and glutathione. Pyruvate as well as alanine production were not significantly influenced by the infection in either hyperoxia or physioxia (Figure 3). Together these results point out a C. parvum-induced increase of intracellular glycolysis and glutaminolysis, independent from oxygen pressure. Glycolysis proved here to play a pivotal role in C. parvum replication. By degrading glucose 
to lactate not only energy is released but cell building blocks are provided to synthesize amino acids, fatty acids and sterols.

Glutaminolysis summarizes the degradation of the amino acid glutamine to pyruvate, $\mathrm{CO}_{2}$, lactate and citrate in the course of these recruiting reactions steps of the citrate cycle. The special role of glutamine metabolism in C. parvum-infected host cells was also confirmed by metabolic changes which occurred when HCT-8 cells were cultivated under glutamine deficiency conditions ( $0.02 \mathrm{mM}$ glutamine). Thus, in glutamine-starved C. parvum-infected host cells, the glycolytic conversion rates increased more than two-fold as reflected by a highly significant increase of glucose consumption and lactate production at both hyperoxia and physioxia (Figure 4). Furthermore, glutamine deficiency seems to be compensated by an increased uptake of other amino acids. Accordingly, aspartate conversion changed from production to consumption and serine consumption increased in glutamine-starved $C$ parvum-infected HTC-8 cells.

Thus, in addition to glucose degradation via glycolysis, the increasingly produced lactate in glutamine supplemented C. parvum-infected HCT-8 cells may also derive from degradation of the amino acid glutamine (glutaminolysis).

In order to further analyze the role of glycolysis and glycolytic-derived ATP production, we subjected C. paroum-infected HCT-8 cells to Seahorse XFp-based analyses on glycolytic responses. Here, glycolytic rate assays revealed an increase of glycolysis in C. paroum-infected HCT- 8 cells ( $p>0.005$; Figure 5a) when compared to non-infected host cells. Likewise, a significant increase in glycolytic ATP production was observed (C. parvum-infected vs. control cells: $p=0.0111$; Figure 5 b) confirming glycolysis's pivotal role as an energy source for $C$. paroum.

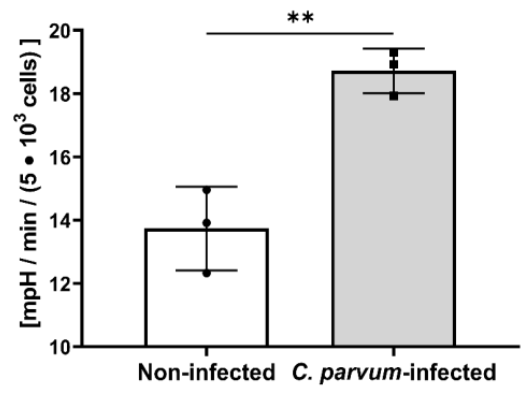

(a)

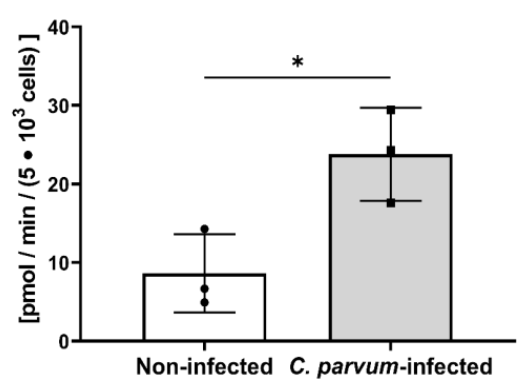

(b)

Figure 5. Effect of C. parvum infection on glycolysis and glycolytic ATP production in HCT-8 cells under hyperoxic $\left(21 \% \mathrm{O}_{2}\right)$ conditions. (a) C. parvum infection-triggered upregulation of glycolysis in HCT-8 cells as evidenced by Seahorse Glycolysis Stress Test Kit. (b) Likewise, significant infectioninduced upregulation of glycolysis-derived ATP was observed. Bar graph shows mean $\pm \mathrm{SD},(n=3)$. $t$-test was use for evaluation of significance $\left(^{*}=p \leq 0.05,{ }^{* *}=p \leq 0.01\right)$.

\subsection{Effects of Selected Metabolic Inhibitors on C. paroum Infection at $5 \%$ and $21 \% \mathrm{O}_{2}$ Conditions}

Based on the impact of $C$. parvum-infection on HCT-8 cell metabolism, we examined the influence of the following metabolic inhibitors on C. parvum infection rates depending on oxygen supply: galloflavin (inhibitor of lactate dehydrogenase) [63], lonidamine [inhibitor of glycolytic hexokinase (HK), mitochondrial pyruvate carrier (MPC), lactate transporters MCT 1, 2 and 4] as well as succinate dehydrogenase (SD) blocking mitochondrial complex II [64-66]. Syrosingopine (inhibitor of MCT1- and MCT4 lactate transporters) [67,68] and compound 968 (inhibitor of glutaminase) [69] (Figure 6). 


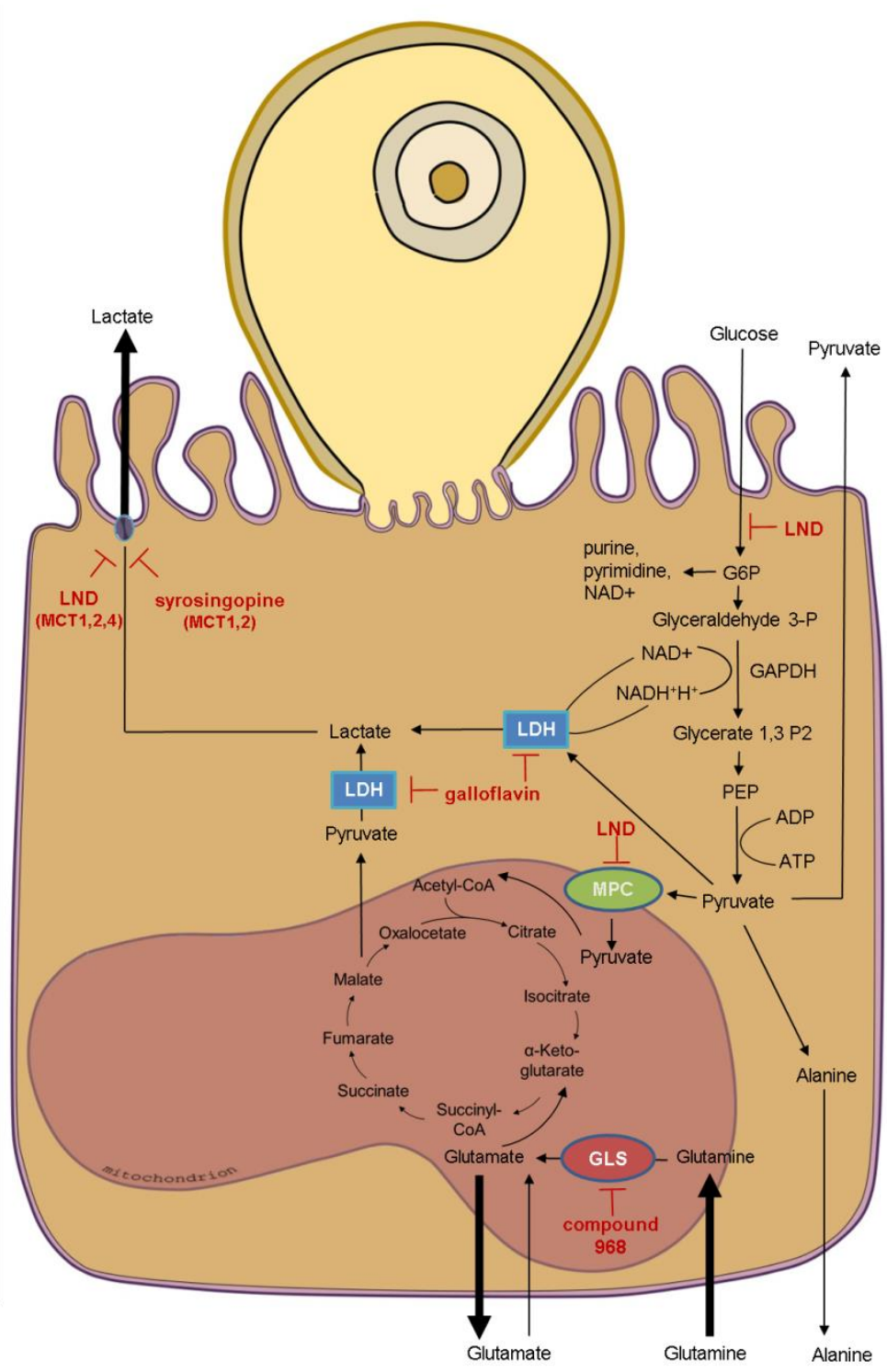

Figure 6. Schematic summary of the metabolic impact of C. parvum infection on HCT-8 cells cultivated in presence of $2 \mathrm{mM}$ glutamine and $21 \%$ oxygen and targets of selected inhibitors. Bold arrows indicate impact on metabolic conversion rates of C. parvum-infected host cells (compare Figure 3). Based on C. parvum-induced alterations of host cell metabolism, the indicated metabolic inhibitors were selected to investigate their potential to inhibit $C$. parvum infection in HCT-8 cells. LND: lonidamine, MPC: mitochondrial pyruvate carrier, GLS: glutaminase, LDH: lactate dehydrogenase, MCT: monocarboxylate transporter.

In preceding dose finding studies, all inhibitors were pretested in uninfected HCT-8 cells for toxicity and glycolysis-lowering effects at different micromolar concentrations (galloflavin: 25, 50, 100, 200, 400, 800, $1600 \mu \mathrm{M}$; lonidamine: 75, 150, 300, $600 \mu \mathrm{M}$; syrosingopine and compound $968: 5,10,20.40,80,160,320 \mu \mathrm{M})$. Overall, there was no evidence of cell toxicity under the treatment ranges used here as detected by both XTT assay and LDH measurements. For controls, cells were mock-treated with $0.1 \%$ DMSO (vehicle) representing 100\% viability. For positive controls (for cell death), cells were treated with $10 \%$ Triton X-100 (Figures S2 and S3). In addition, no alteration of host cell phenotype was visible microscopically at any of the here selected treatment-inhibitor concentration (data not shown). As measured by Glycolysis Stress Test Kit ${ }^{\circledR}$ (Agilent, Rathingen, Germany), all inhibitors led to a significant reduction of glycolysis in uninfected cells, even though to different extents (Figure 7, Figures S5-S8). Of note, compound 968, which represents a 
potent glutaminase inhibitor, also showed a highly significant glycolysis-blocking efficacy at low micromolar range $(10-20 \mu \mathrm{M}$, Figure 7$)$.
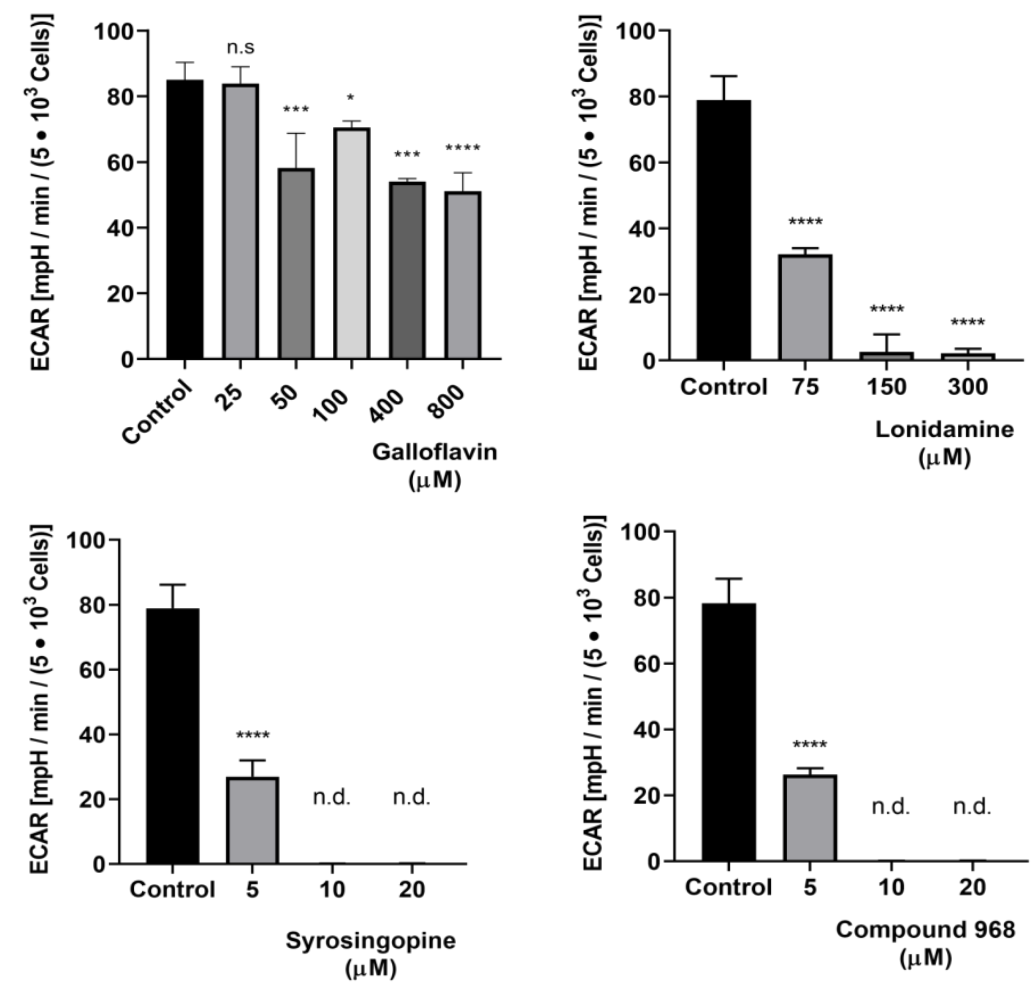

Figure 7. Effects of galloflavin, lonidamine, syrosingopine and compound 968 treatments on glycolysis in uninfected HCT-8 cells cultivated at hyperoxic $\left(21 \% \mathrm{O}_{2}\right)$ condition. Glycolysis stress test revealed a significant reduction of glycolytic responses by selected inhibitors. Bars represents mean $\pm \mathrm{SD},(n=3)$. Data were evaluated for significance by one-way analyses of variance (ANOVA) followed by Dunnett's test. n.s = non-significant, n.d. $=$ non-detectable, ${ }^{*}=p \leq 0.05,{ }^{* * *}=p \leq 0.001$, $* * * *=p \leq 0.0001$.

This observation can be explained by the fact that in infected and uninfected HCT8 cells glucose consumption increased with increasing glutamine consumption which means that glutaminolytic and glycolytic conversion rates positively influence each other (Figure S4) [32]. Based on these preliminary results, the following inhibitor concentrations were chosen to analyse their effects on $C$. parvum infection under physioxic and hyperoxic in vitro conditions: $400 \mu \mathrm{M}$ galloflavin, $150 \mu \mathrm{M}$ lonidamine, $10 \mu \mathrm{M}$ syrosingopine and $10 \mu \mathrm{M}$ compound 968 . The corresponding experimental protocol is described in Supplementary data 1 . Overall, treatments with all compounds led to a significant reduction of C. parvum infection independent from current $\mathrm{O}_{2}$ conditions (galloflavin and lonidamine at both $21 \%$ and $\mathrm{O}_{2} 5 \% \mathrm{O}_{2}: p<0.0022$, syrosingopine and compound 968 at both $\mathrm{O}_{2}$ conditions: $p<0.0022$ ). Thus, galloflavin, lonidamine, syrosingopine and compound 968 treatments induced a reduction of intracellular C. parvum infection of $80 \% / 88 \%, 90 \% / 81 \%$, $71 \% / 89 \%$ and $81 \% / 97 \%$ under $5 \% / 21 \% \mathrm{O}_{2}$ conditions, respectively (Figure 8 ). 

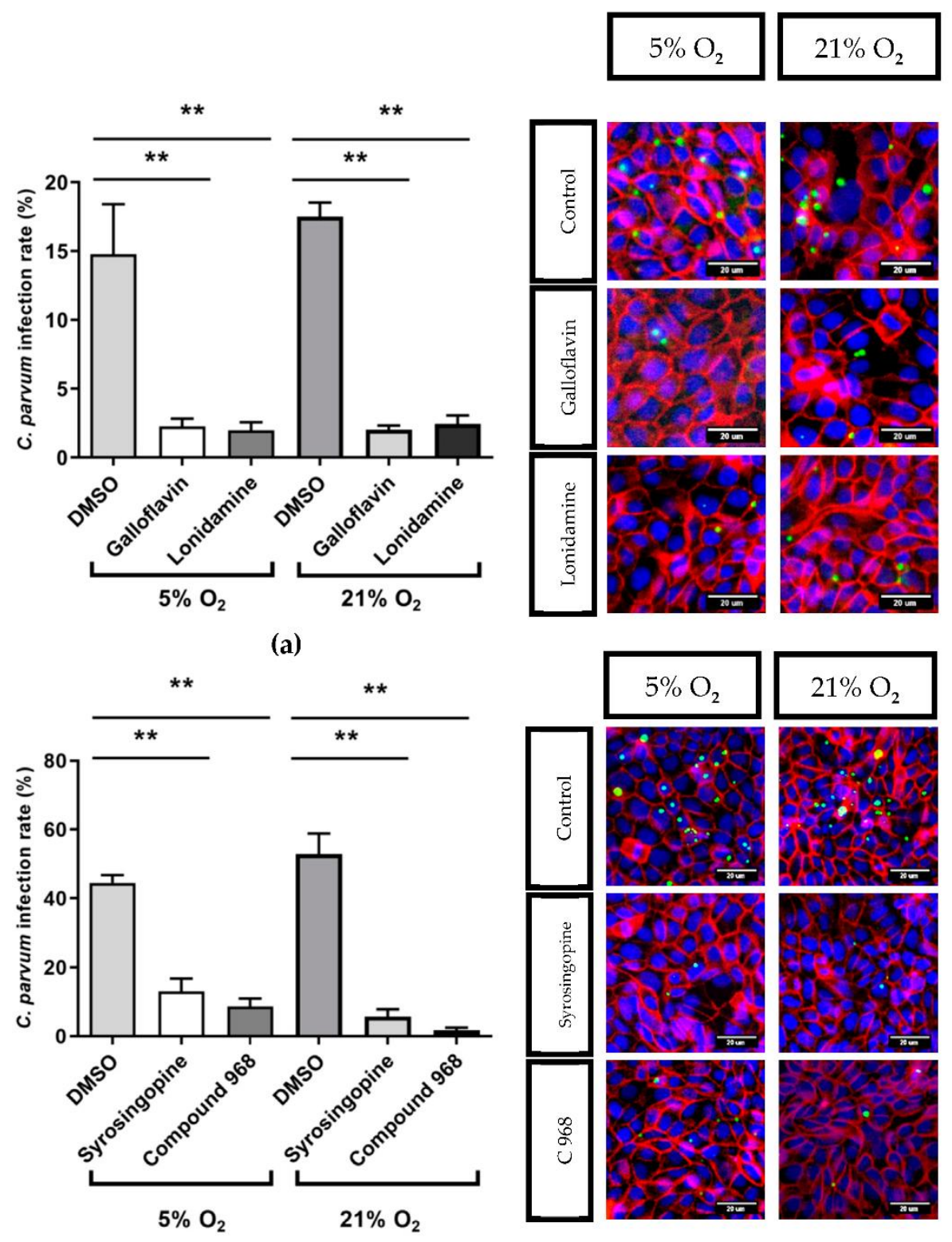

(b)

Figure 8. Effects of galloflavin $(400 \mu \mathrm{M})$, lonidamine $(150 \mu \mathrm{M})(\mathbf{a})$, syrosingopine $(10 \mu \mathrm{M})$ and compound $968(10 \mu \mathrm{M})(\mathbf{a}, \mathbf{b})$ treatments on C. parvum infection rates in HCT-8 cells cultivated at $21 \% \mathrm{O}_{2}$ and $5 \% \mathrm{O}_{2}$, and exemplary illustrations of respective inhibition assays. C. parvum was stained with VVL, green; host -cell membranes and nuclei were labelled with anti-ß-catenin (red) and Hoechst (blue), respectively. Bars show means $\pm \mathrm{SD},(n=6)$. For evaluation of significance $t$-test was performed. ${ }^{* *}=p \leq 0.01$.

To further analyze the impact of the different metabolic inhibitors on the energetic status of $C$. parvum-infected host cells, extracellular flux analyses were performed applying Glycolysis Stress Test ${ }^{\circledR}$ (Agilent, Rathingen, Germany). Therefore, C. parvum-infected HCT- 8 and non-infected controls were subjected to measurements of ECAR and OCR by Seahorse instrumentation and related data were plotted as energetic profiles thereby correlating both measurements and showing a general overview of host cellular energetic status under different treatments (Figure 9 first column). 
(a)

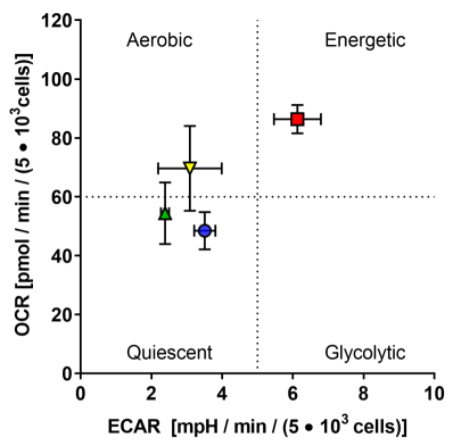

$\left.\begin{array}{ll}\text { - } & \text { Non-infected } \\ \text { C } & \text { C. parvum-infected }\end{array}\right]$ Non-treated

Non-infected

$\left.\begin{array}{ll}\Delta & \text { Non-infected } \\ \nabla & \text { C. parvum-infected }\end{array}\right]$ Galloflavin $400 \mu \mathrm{M}$

(b)

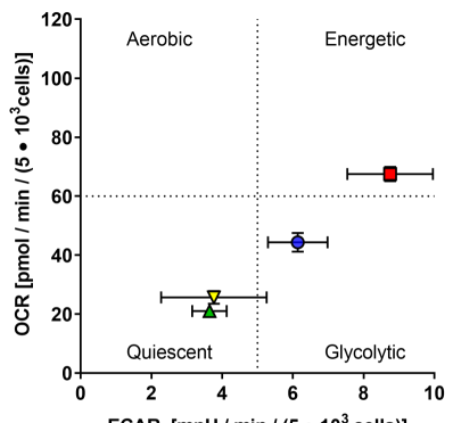

ECAR $\left[\mathrm{mpH} / \mathrm{min} /\left(5 \bullet 10^{3}\right.\right.$ cells $\left.)\right]$

$$
\begin{aligned}
& \left.\begin{array}{l}
\text { O Non-infected } \\
\text { [ C. parvum-infected }
\end{array}\right] \text { Non-treated } \\
& {\left[\begin{array}{ll}
\Delta & \text { Non-infected } \\
\nabla & \text { C. parvum-infected }
\end{array}\right] \text { Lonidamine } 150 \mu \mathrm{M}}
\end{aligned}
$$

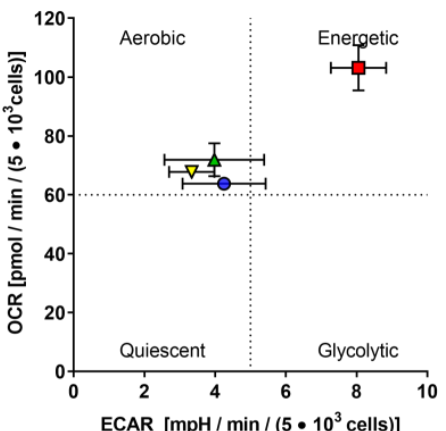

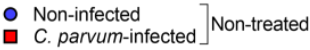

$\Delta$ Non-infected

$\nabla$ C. parvum-infected Syrosingopine $10 \mu \mathrm{M}$
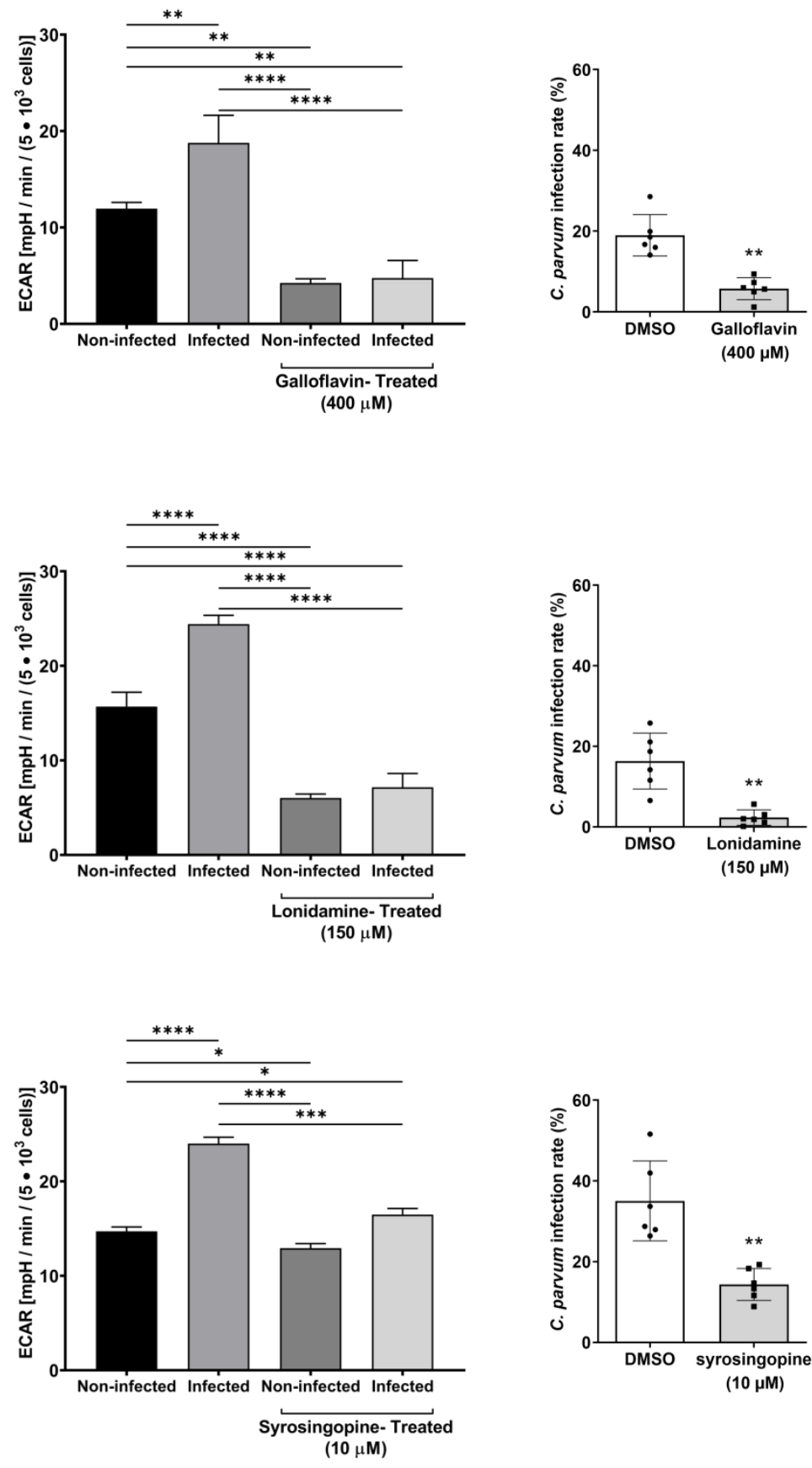

$(10 \mu \mathrm{M})$

Figure 9. Cont. 
(d)

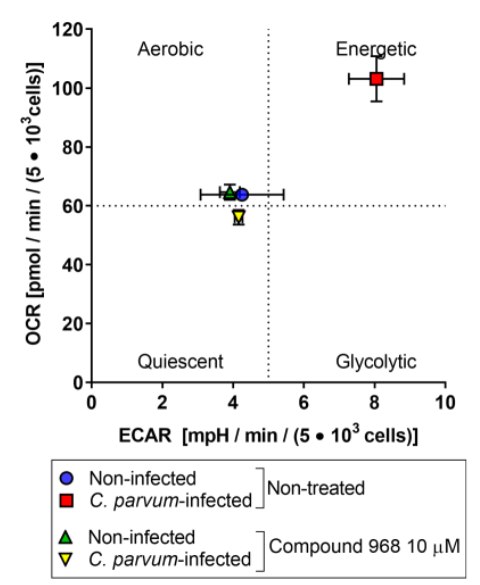

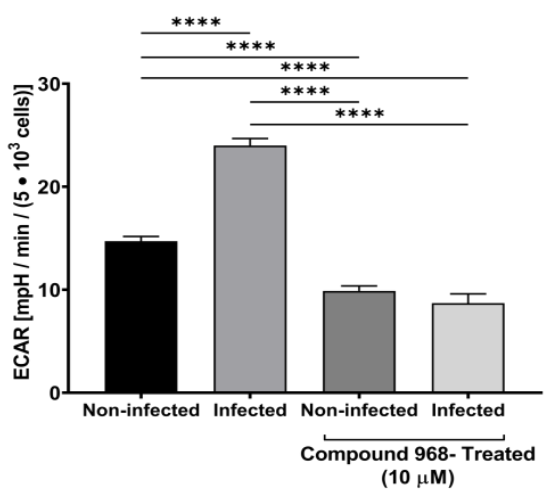

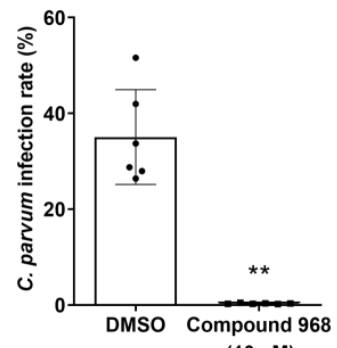

$(10 \mu \mathrm{M})$

Figure 9. Impact of $C$. parvum infection and inhibitor treatments on HCT-8 energetic profiles: (First column) The current energetic profiles are plotted by presenting OCR- and ECAR values in HCT-8 ( $n=3$, each condition). (Second column) Effect of galloflavin (a), lonidamine (b), syrosingopine (c) and compound 968 (d) treatments on energetic profiles of HCT-8 infected and non-infected controls: The glycolytic function was evaluated in C. parvum-infected host cells under $21 \% \mathrm{O}_{2}$ by means of Seahorse Glycolysis Stress Test. Glycolytic activities in treated and infected cells were compared with untreated and infected cells, revealing a significant reduction in glycolytic capacity. (Third column) Thus, reduced glycolytic capacity corresponds with significant reduction of infection rates. Bars present means $\pm \mathrm{SD}$, (Energy maps, First column, $n=3$; Glycolysis, second column $n=3$, Infection rates, third column, $n=6$ ). For evaluation of significance on glycolytic function (second column) one-way analyses of variance (ANOVA) followed by Dunnett's test was performed. Significances of inhibitors effects on infection rates (third column) were estimated by means of $t$-test. ${ }^{*}=p \leq 0.05,{ }^{* *}=p \leq 0.01,{ }^{* * *}=p \leq 0.001,{ }^{* * * *}=p \leq 0.0001$.

The related test protocol includes initial measurements of basal non-glycolytic acidification, followed by reactions upon sequential supplementation of glucose (induces glycolysis), oligomycin (blocks ATP synthase) and 2-deoxy-D-glucose (blocks glycolysis) (for back-calculation of glycolytic reserve) via instrument-own injection ports. Energetic maps (Figure 9, first column) revealed that $C$. parvum infection was generally linked to a shift towards a high energetic status and likewise to a rise of glycolysis (Figure 9, second column) when compared to non-infected control cells. When inhibitors were applied, the high energetic status of cells changed and moved back towards the lower energetic status of non-infected control cells. The overall energetic behaviour of inhibitor-treated cells was mirrored by decreased ECAR values. Inhibitor-induced decreases in glycolytic activity was also related with a significant reduction in C. parvum infection rates $(p=0.0022$ for all treatments) (third column of Figure 9). Related data on the glycolytic capacity, glycolytic reserve and non-glycolytic acidification are presented in supplementary files (Figures S5-S8).

\section{Discussion}

Here we analyzed the effect of $C$. parvum on the metabolic signatures of infected HCT-8 under physioxia $\left(5 \% \mathrm{O}_{2}\right)$ to mimic in vivo physiological gut conditions and found that all, glycolysis, glutaminolysis and degradation of the amino acid serine seemed essential for parasite replication. Whilst $C$. parvum has own glycolytic capacities, it lacks the metabolic equipment for glutaminolysis rendering the latter as pure host cell-supplied activity. Glutaminolysis recruits reaction steps of the citrate cycle which is not present in C. parvum. The significant impact of metabolic inhibitors targeting glutamine consumption and lactate release on C. parvum infection confirmed the high relevance of both energetic pathways for C. parvum replication. Moreover, novel live cell 3D-holotomographic microscopy was performed to unveil parasite-host cell interactions, precise localization of sporozoites and intracellular, trophozoite, meront and gamont stages.

Due to C. parvum-minimal own metabolic capacities which are mainly limited to glycolysis, the parasite must modulate host cell metabolism for its intracellular replica- 
tion $[14-16,18,28]$. In line with these restricted metabolic capacities, phylogenetic findings advocate that ancestral apicomplexan protozoa originally used myzocytosis, a predatory behaviour, by piercing host cell membranes in order to suck nutrients from the host $[15,19,36]$. Interestingly, C. parvum resides intracellularly with an epicellular location forming a feeder organelle, which is in contact with the host cell cytoplasm. This feeder organelle can be seen as a pleisiomorphic feature of such ancestral predatory behaviour, which ensures nutrient uptake from host cells and is now referred to as "cell vampirism" [20,36,69-71]. We also detected feeder organelles in early C. paroum trophozoite stages by means of live cell 3D-holotomography microscopy, pointing out cell vampirism as an important strategy for successful nutritional uptake.

In the current study we found significant differences in metabolic conversion rates between C. parvum-infected and non-infected host cells. A striking example is the increased lactate production rate, which was detected by two independent methods, i.e., by photometric lactate measurements and by determining acidification of $C$. parvum-infected cell-derived supernatants under both physioxia and hyperoxia. Our results confirm recent findings on C. parvum- and C. hominis-infected mice models [26]. Likewise, D-lactatederived acidosis has also been described in neonatal calves experiencing clinical cryptosporidiosis [72,73]. Lactate is a final product of glucose degradation in differentiated cells under hypoxic conditions and in proliferating cells under both $21 \%$ oxygen and hypoxia. In line, we found significant enhanced glucose consumption rates in C. parvum-infected HCT- 8 cells when cultured in the presence of $21 \% \mathrm{O}_{2}$. Likewise, Seahorse-based analyses indicated a significant up-regulation of glycolysis and glycolytic ATP synthesis and showed significantly enhanced ECAR values in C. parvum-infected host cells. Our findings in principle are in agreement with previously described $C$. parvum-induced metabolic changes in host cell cultures [26], in C. hominis- and C. parvum-infected animals $[25,26]$ and with data on transcription control of glycolysis-related genes in C. parvum infected HCT-8 cells [23].

Of note, in addition to glucose, amino acids, such as glutamine and serine, can also be degraded to lactate. In C. parvum-infected HCT-8 cells, glutamine consumption significantly increased at both hyperoxia and physioxia. In addition, serine conversion was reversed from production in control cells to consumption in C. parvum-infected cells at physioxia. The parallel change in glutamate conversion from consumption to production in C. parvum-infected HCT-8 at hyperoxia and physioxia indicates that a certain proportion of consumed glutamine was not introduced into citric acid cycle but instead released as glutamate thereby contributing to the acidification of the medium. The crucial role of glutamine metabolism in C. parvum-infected host cells was confirmed by metabolic changes which occurred at glutamine-starved in vitro culture conditions $(0.02 \mathrm{mM}$ glutamine). In glutamine-starved C. parvum-infected host cells, the glycolytic conversion rates increased more than two-fold at both hyperoxia and physioxia as reflected by a highly significant increase in glucose consumption and lactate production. Accordingly, in glutamine-supplemented medium ( $2.0 \mathrm{mM}$ glutamine) significantly increased glutamine consumption and glutamate production rates were found in C. parvum-infected host cells under hyperoxia, as well as under physioxia.

Together, these metabolic findings evidenced a key role of glutaminolysis in parasitized host cells as also described for other apicomplexan parasites, such as T. gondii and Besnoitia besnoiti [31-33]. In the blood of mammalian species, glutamine is an important vehicle of nitrogen, i.e., for nitrogen transport from muscles to liver. Thus, glutamine represents the amino acid with the highest concentration in the blood in mammalians. For C. parvum development, glutamine appears to be essential. Glutamine is an important substrate in purine and pyrimidine synthesis. Additional functions of glutamine rely on its conversion to glutamate, which is a precursor for the synthesis of different amino acids and glutathione, which is also used to fuel the TCA cycle. Accordingly, besides glycolysis, glutaminolysis is another important energy source in fast proliferating cells, such as intestinal epithelial cells and tumor cells $[43,44,68,74-76]$. Of note, dynamic cell type-specific interactions between glucose and glutamine metabolism are described in 
several non-tumor and tumor cells $[54,76,77]$. This interplay was also the case for the HCT-8 cell line used in this study. In future experiments, we would like to extend the current metabolic characterization to primary intestinal epithelial cells to simulate human and animal C. parvum-infections in more realistic cell culture systems. Consistently, there are several studies reporting a key role of glutamine in intestinal epithelial cell proliferation [78-80], epithelial cell tight junction integrity [81,82] and in local gut-driven host innate immune reactions $[83,84]$. In addition, there is also some evidence on glutamine acting as amino acid for maintenance of intestinal barrier function in children [85,86], which are actually the most vulnerable age group of human cryptosporidiosis infections in developing countries worldwide [4-6]. The same holds true for lactate, which induces fast and strong activation of mammalian polymorphonuclear neutrophils (PMN) resulting in the formation of neutrophil extracellular traps (NETs) [87-89] which represents an essential innate effector mechanism against various invasive pathogens [90], including protozoan and helminth parasites [90]. In line, C. paroum-triggered NET formation was also reported to occur in PMN of human and bovine origin [91].

Glutamine has also been proven to decrease intestinal permeability and bacterial translocation in mice and in critical cryptosporidiosis patients [92-94]. In line with our present results, indicating a pivotal role of glutamine for C. parvum replication, treatments with compound 968, which blocks glutamine degradation by inhibiting mitochondrial glutaminase, led to a highly significant reduction of C. parvum development. Compound 968 is a tetrahydrobenzo[a] derivative capable of blocking Rho GTPase-induced transformation in fibroblasts and inhibiting cancer cell growth [69]. Interestingly, after achieving reversion of compound 968 by adding $\alpha$-ketoglutarate $(\alpha-K G)$ it became clear that fuelling of TCA cycle through glutaminolysis was critical for tumour growth $[69,95]$. Similar to glucose, the importance of glutamine for cell growth lies both in regeneration of energy and in the supply of starting molecules (here carbon atoms and nitrogen) for biosynthesis of cell building blocks. In fact, a high demand of cell building blocks is present in rapidly dividing cells, such as intestinal epithelial cells, which show a high cellular turnover $[78,79,96,97]$. Interestingly, compound 968 did also inhibit glycolysis in C. parvum-infected HCT-8 cells as reflected by a downregulation of extracellular acidification rate. In non-infected and $C$. parvum-infected HCT-8 cells, an increase in glutamine concentration correlated with an increase in glucose consumption. An explanation for this correlation is that glutamate, the product of the glutaminase reactions, provides the amino group for serine synthesis from the glycolytic intermediate glycerate 3-P. Indeed, serine consumption from culture medium significantly increased in glutamine-starved C. parvum-infected cells, presumably due to an impairment of intracellular serine synthesis. Serine is a precursor for the synthesis of cysteine as well as glycine and N5N10 methylene tetrahydrofolate. The latter two are substrates for the synthesis of nucleic acids. [33,74,98]. Cysteine and glycine are necessary for the synthesis of glutathione which plays an important role in detoxification of ROS. Of note, high ROS concentrations are known to impair parasite viability and represent a pivotal mechanism of early host innate immune reactions directed against protozoan and metazoan parasites $[99,100]$.

To address the role of both lactate and the glucose-lactate-axis in physioxic and hyperoxic C. parvum-infected HCT-8 cells, we additionally investigated the impact of galloflavin, lonidamine and syrosingopine on infection rates and on the metabolism of HCT-8 cells. It is important to consider that glycolysis-related inhibitors will not exclusively target metabolic pathways of host cells but also of $C$. paroum-driven glycolysis $[18,29,60]$. Lactate is produced by lactate dehydrogenase-catalyzed reduction of pyruvate thereby regenerating cytosolic NAD+ which is the substrate of the glycolytic GAPDH reaction. Thus, NAD+ deficiency leads to an inhibition of glycolysis. Galloflavin inhibits the lactate dehydrogenase. In accordance to other studies investigating the impact of lactate dehydrogenase inhibitors on Cryptosporidium replication in presence of $21 \%$ oxygen [27,29,30], galloflavin treatments significantly blocked C. parvum infection rates under both oxygen conditions, thereby underlining the crucial role of lactate synthesis even in conditions of physioxia. The increased 
amount of lactate released by C. parvum-infected host cells may derive from an enhanced breakdown of glucose (glycolysis) or of the amino acids glutamine (glutaminolysis) and serine (serinolysis).

In order to avoid an acidification of the cytoplasm, lactate is exported from cells via monocarboxylate transporters (MCTs). Accordingly, we investigated the impact of two different MCT inhibitors on C. paroum-infected HCT-8 cells: syrosingopine, which inhibits MCT 1 and MCT2 $[67,68]$ and lonidamine, which is a MCT1-, 2, and 4 inhibitor [66]. As symporters, MCT 1-4 transport lactate and protons into the extracellular space, thus contributing to $\mathrm{pH}$ regulation especially during glycolysis [66,101]. MCT inhibition prevents the release of lactate regardless of the metabolic origin (i.e., glycolysis, glutaminolysis or serinolysis). In contrast to syrosingopine, lonidamine induces-besides MCT blockagealso an inhibition of hexokinase (=enzyme in glycolysis), succinate dehydrogenase (=enzyme in citric acid cycle) and mitochondrial complex II (=component of OXPHOS) $[64,65]$. Both syrosingopine- and lonidamine-induced significant inhibition of $C$. parvum infection in HCT-8 cells independent from the oxygen pressure (hyperoxia or physioxia). Interestingly, in the case of lonidamine, which in addition to MCTs also targets hexokinase, succinate dehydrogenase and complex II, a 15-fold higher concentration had to be used in order to obtain the same level of inhibition of $C$. parvum infection as the obtained by using syrosingopine.

The exact molecular mechanisms on how $C$. parvum sporozoites attach and penetrate intestinal mucus is still not fully understood $[15,36]$. Effective blockage of active C. parvumsporozoite intestinal mucus migration could constitute an important cornerstone for drug development, since this event is critical for the establishment of infection. Thus, the possibility to follow C. parvum development in live cells and real time enables us to better understand such fundamental events. Accordingly, the label-free RI-based digital staining has successfully been used to unveil the intracellular architecture and parasite-host cell interactions of related apicomplexans $[102,103]$ and, more recently, cytopathogenic effects of viruses [104]. In this sense, we here presented first live cell 3D-holotomographic microscopy analyses of $C$. paroum infection. The, refractive index- and nanoscale membrane fluctuationbased analyses revealed feasible and non-invasive approaches to study sporozoite host cell invasion and early sporozoite/host cell interactions [15,102,103].

\section{Conclusions}

Metabolic profiling of C. parvum-infected cells evidenced here a parasite dependentupregulation of glycolysis. The low ATP production efficiency of glycolysis compared to that obtained by oxidative phosphorylation clearly points out a demand of macromolecules and reductive agents necessary for $C$. parvum rapid replication. Interestingly, the correlation found here in glycolysis and glutaminolysis under physiologic $\mathrm{O}_{2}$ conditions agree with previous postulates on other C. parvum-related parasites (e.g., T. gondii), provoking theorization about an evolutionary convergence of apicomplexans and cancer cells. Likewise, we confirm here a C. paroum dependence on glutaminolysis, rendering the least one as potential anti-cryptosporidial target.

Moreover, we here showed the usefulness of live cell 3D-holotomographic microscopy for further detailed illustrations, such as the formation of lipid droplets, feeder organelle, parasitophorous vacuole (PV) changes and/or mitochondrial movements in C. parvuminfected host epithelial cells. This technique, combined with SEM and transmission electron microscopy (TEM) will help to better understand the dynamic and complex parasite-host cell interactions, such as formation of feeder organelle and myzocytosis, but also allow to precisely evaluate possible impacts of novel anti-cryptosporidial drugs on C. paroum intracellular replication.

Supplementary Materials: The following are available online at https://www.mdpi.com/2079-7 737/10/1/60/s1, Figure S1: Treatment/infection scheme. Figure S2: Viability assays of host-cells treated with selected inhibitors by means of XTT. Figure S3: Viability assays of host-cells treated with selected inhibitors by means of LDH measurement. Figure S4: Correlation between glutamine 
consumption and glucose consumption in C. parvum-infected HCT-8 cells under 5\% oxygen condition. Figures S5-S8: Glycolytic capacity (a), glycolytic, reserve (b) and non-glycolytic acidification (c) of C. paroum-infected-HCT- 8 under $21 \% \mathrm{O}_{2}$ and relative effects of galloflavin (Figure S5), lonidamine (Figure S6), syrosingopine (Figure S7) and compound 968 (Figure S8) treatments.

Author Contributions: Conceived and designed the study: C.H., A.T., S.M., L.M.R.S. Provided sporulated C. parvum oocysts: A.D. Performed parasite infections, cytotoxic evaluation experiments, Seahorse measurements and analysis: J.V. Processed and analysed the in vitro host cell infections: J.V., L.M.R.S., Z.V. Performed the live cell 3D-Holotomographic microscopy-pictures and their analysis: Z.V. Performed the scanning electronic microscopic work: U.G. Supervised laboratory work: C.H., A.T., L.M.R.S., S.M., Z.V. Performed statistical analysis: K.F., L.M.R.S., J.V. Writing and revision of the manuscript: J.V., Z.V., L.M.R.S., C.H., A.T., S.M. All authors read and approved the final manuscript.

Funding: This project was funded by the LOEWE Centre DRUID (Novel Drug Targets against Poverty-Related and Neglected Tropical Infectious Diseases [project D5]).

Informed Consent Statement: Not applicable.

Acknowledgments: We are grateful to Marion Sparenberg (Justus Liebig University Giessen, Unit for Biomathematics and Data Processing) for her data analysis and kind suggestions. We deeply thank Christine Henrich (Justus Liebig University Giessen, Institute of Parasitology) as well as Bianca Kulik and Sandra Rühl (Justus Liebig University Giessen, Institute of Veterinary Physiology and Biochemistry) for their excellent technical assistance in performance of molecular analyses and measurements on metabolic conversion rates. We also thank Zaida Rentería-Solís (University of Leipzig, Institute for Parasitology) for providing C. parvum-oocysts and plasmid DNA, Anika Seipp (Justus Liebig University Giessen, Institute of Anatomy and Cell Biology) for her assistance in SEM-based analysis, and ReneoRisin for the illustration presented in Figure 6.

Conflicts of Interest: The authors declare that they have no competing interest.

\section{References}

1. Raccurt, C.P. Worldwide human zoonotic cryptosporidiosis caused by Cryptosporidium felis. Parasite 2007, 14, 15-20. [CrossRef] [PubMed]

2. Baydoun, M.; Vanneste, S.B.; Creusy, C.; Guyot, K.; Gantois, N.; Chabe, M.; Delaire, B.; Mouray, A.; Baydoun, A.; Forzy, G.; et al. Three-dimensional (3D) culture of adult murine colon as an in vitro model of cryptosporidiosis: Proof of concept. Sci. Rep. 2017, 7, 17288. [CrossRef] [PubMed]

3. O'Connor, R.M.; Shaffie, R.; Kang, G.; Ward, H.D. Cryptosporidiosis in patients with HIV/AIDS. AIDS 2011, 25, 549. [CrossRef]

4. Liu, L.; Johnson, H.L.; Cousens, S.; Perin, J.; Scott, S.; Lawn, J.E.; Rudan, I.; Campbell, H.; Cibulskis, R.; Li, M.; et al. Global, regional, and national causes of child mortality: An updated systematic analysis for 2010 with time trends since 2000. Lancet 2012, 379, 2151-2161. [CrossRef]

5. Hedstrom, L. Cryptosporidium: A first step toward tractability. Trends Parasitol. 2015, 31, 401-402. [CrossRef]

6. Kotloff, K.L.; Nataro, J.P.; Blackwelder, W.C.; Nasrin, D.; Farag, T.H.; Panchalingam, S.; Wu, Y.; Sow, S.O.; Sur, D.; Breiman, R.F.; et al. Burden and aetiology of diarrhoeal disease in infants and young children in developing countries (the Global Enteric Multicenter Study, GEMS): A prospective, case-control study. Lancet 2013, 382, 209-222. [CrossRef]

7. Striepen, B. Parasitic infections: Time to tackle cryptosporidiosis. Nature 2013, 503, 189. [CrossRef]

8. Manjunatha, U.H.; Vinayak, S.; Zambriski, J.A.; Chao, A.T.; Sy, T.; Noble, C.G.; Bonamy, G.M.C.; Kondreddi, R.R.; Zou, B.; Gedeck, P.; et al. A Cryptosporidium PI(4)K inhibitor is a drug candidate for cryptosporidiosis. Nature 2017, 546, 376-380. [CrossRef]

9. Ryan, U.; Hijjawi, N.; Xiao, L. Foodborne cryptosporidiosis. Int. J. Parasitol. 2018, 48, 1-12. [CrossRef]

10. Gibson, A.R.; Striepen, B. Cryptosporidium. Curr. Biol. 2018, 28, R193-R194. [CrossRef]

11. Amadi, B.; Mwiya, M.; Sianongo, S.; Payne, L.; Watuka, A.; Katubulushi, M.; Kelly, P. High dose prolonged treatment with nitazoxanide is not effective for cryptosporidiosis in HIV positive Zambian children: A randomised controlled trial. BMC Infect. Dis. 2009, 9, 195. [CrossRef] [PubMed]

12. Bessoff, K.; Sateriale, A.; Lee, K.K.; Huston, C.D. Drug Repurposing Screen Reveals FDA-Approved Inhibitors of Human HMG-CoA Reductase and Isoprenoid Synthesis That Block Cryptosporidium parvum Growth. Antimicrob. Agents Chemother. 2013, 57, 1804-1814. [CrossRef] [PubMed]

13. Abrahamsen, M.S.; Templeton, T.J.; Enomoto, S.; Abrahante, J.E.; Zhu, G.; Lancto, C.A.; Deng, M.; Liu, C.; Widmer, G.; Tzipori, S.; et al. Complete Genome Sequence of the Apicomplexan, Cryptosporidium parvum. Science 2004, 304, 441-445. [CrossRef]

14. Mauzy, M.J.; Enomoto, S.; Lancto, C.A.; Abrahamsen, M.S.; Rutherford, M.S. The Cryptosporidium parvum Transcriptome during In Vitro Development. PLoS ONE 2012, 7, e31715. [CrossRef] [PubMed]

15. Clode, P.L.; Koh, W.H.; Thompson, R.C.A. Life without a Host Cell: What is Cryptosporidium? Trends Parasitol. 2015, 31, 614-624. [CrossRef] 
16. Liu, S.; Roellig, D.M.; Guo, Y.; Li, N.; Frace, M.A.; Tang, K.; Zhang, L.; Feng, Y.; Xiao, L. Evolution of mitosome metabolism and invasion-related proteins in Cryptosporidium. BMC Genom. 2016, 17, 1006. [CrossRef]

17. Morada, M.; Lee, S.; Gunther-Cummins, L.; Weiss, L.M.; Widmer, G.; Tzipori, S.; Yarlett, N. Continuous culture of Cryptosporidium parvum using hollow fiber technology. Int. J. Parasitol. 2016, 46, 21-29. [CrossRef]

18. Xu, Z.; Guo, Y.; Roellig, D.M.; Feng, Y.; Xiao, L. Comparative analysis reveals conservation in genome organization among intestinal Cryptosporidium species and sequence divergence in potential secreted pathogenesis determinants among major human-infecting species. BMC Genom. 2019, 20, 406. [CrossRef]

19. Schnepf, E.; Deichgräber, G. "Myzocytosis", a kind of endocytosis with implications to compartmentation in endosymbiosis. Naturwissenschaften 1984, 71, 218-219. [CrossRef]

20. Barta, J.R.; Thompson, R.C.A. What is Cryptosporidium? Reappraising its biology and phylogenetic affinities. Trends Parasitol. 2006, 22, 463-468. [CrossRef]

21. Leander, B.S.; Keeling, P.J. Morphostasis in alveolate evolution. Trends Ecol. Evol. 2003, 18, 395-402. [CrossRef]

22. Cavalier-Smith, T. Gregarine site-heterogeneous $18 \mathrm{~S}$ rDNA trees, revision of gregarine higher classification, and the evolutionary diversification of Sporozoa. Eur. J. Protistol. 2014, 50, 472-495. [CrossRef]

23. Xu, T.; Ping, J.; Yu, Y.; Yu, F.; Yu, Y.; Hao, P.; Li, X. Revealing parasite influence in metabolic pathways in Apicomplexa infected patients. BMC Bioinform. 2010, 11, S13. [CrossRef]

24. Ng, J.S.Y.; Ryan, U.; Trengove, R.D.; Maker, G.L. Development of an untargeted metabolomics method for the analysis of human faecal samples using Cryptosporidium-infected samples. Mol. Biochem. Parasitol. 2012, 185, 145-150. [CrossRef]

25. Hublin, J.S.Y.N.; Ryan, U.; Trengove, R.; Maker, G. Metabolomic Profiling of Faecal Extracts from Cryptosporidium parvum Infection in Experimental Mouse Models. PLoS ONE 2013, 8, e77803. [CrossRef]

26. Miller, C.N.; Panagos, C.G.; Mosedale, W.R.T.; Kváč, M.; Howard, M.J.; Tsaousis, A.D. NMR metabolomics reveals effects of Cryptosporidium infections on host cell metabolome. Gut Pathog. 2019, 11, 13. [CrossRef]

27. Zhang, H.; Guo, F.; Zhu, G. Cryptosporidium Lactate Dehydrogenase Is Associated with the Parasitophorous Vacuole Membrane and Is a Potential Target for Developing Therapeutics. PLoS Pathog. 2015, 11, e1005250. [CrossRef]

28. Yu, Y.; Zhang, H.; Guo, F.; Sun, M.; Zhu, G. A unique hexokinase in Cryptosporidium parvum, an apicomplexan pathogen lacking the Krebs cycle and oxidative phosphorylation. Protist 2014, 165, 701-714. [CrossRef]

29. Cook, W.J.; Senkovich, O.; Hernandez, A.; Speed, H.; Chattopadhyay, D. Biochemical and structural characterization of Cryptosporidium parvum Lactate dehydrogenase. Int. J. Biol. Macromol. 2015, 74, 608-619. [CrossRef]

30. Li, K.; Nader, S.M.; Zhang, X.; Ray, B.C.; Kim, C.Y.; Das, A.; Witola, W.H. Novel lactate dehydrogenase inhibitors with in vivo efficacy against Cryptosporidium parvum. PLoS Pathog. 2019, 15, e1007953. [CrossRef]

31. Blume, M.; Rodriguez-Contreras, D.; Landfear, S.; Fleige, T.; Soldati-Favre, D.; Lucius, R.; Gupta, N. Host-derived glucose and its transporter in the obligate intracellular pathogen Toxoplasma gondii are dispensable by glutaminolysis. Proc. Natl. Acad. Sci. USA 2009, 106, 12998-13003. [CrossRef] [PubMed]

32. Nitzsche, R.; Zagoriy, V.; Lucius, R.; Gupta, N. Metabolic Cooperation of Glucose and Glutamine Is Essential for the Lytic Cycle of Obligate Intracellular Parasite Toxoplasma gondii. J. Biol. Chem. 2016, 291, 126-141. [CrossRef] [PubMed]

33. Taubert, A.; Hermosilla, C.; Silva, L.M.R.; Wieck, A.; Failing, K.; Mazurek, S. Metabolic signatures of Besnoitia besnoiti-infected endothelial host cells and blockage of key metabolic pathways indicate high glycolytic and glutaminolytic needs of the parasite. Parasitol. Res. 2016, 115, 2023-2034. [CrossRef]

34. Makiuchi, T.; Nozaki, T. Highly divergent mitochondrion-related organelles in anaerobic parasitic protozoa. Biochimie 2014, 100, 3-17. [CrossRef]

35. Ryan, U.; Paparini, A.; Monis, P.; Hijjawi, N. It's official—Cryptosporidium is a gregarine: What are the implications for the water industry? Water Res. 2016, 105, 305-313. [CrossRef]

36. Borowski, H.; Clode, P.L.; Thompson, R.C.A. Active invasion and/or encapsulation? A reappraisal of host-cell parasitism by Cryptosporidium. Trends Parasitol. 2008, 24, 509-516. [CrossRef]

37. Borowski, H.; Thompson, R.C.A.; Armstrong, T.; Clode, P.L. Morphological characterization of Cryptosporidium parvum life-cycle stages in an in vitro model system. Parasitology 2010, 137, 13-26. [CrossRef]

38. Helander, H.F.; Fändriks, L. Surface area of the digestive tract-revisited. Scand. J. Gastroenterol. 2014, 49, 681-689. [CrossRef]

39. Carreau, A.; Hafny-Rahbi, B.E.; Matejuk, A.; Grillon, C.; Kieda, C. Why is the partial oxygen pressure of human tissues a crucial parameter? Small molecules and hypoxia. J. Cell. Mol. Med. 2011, 15, 1239-1253. [CrossRef]

40. Zheng, L.; Kelly, C.J.; Colgan, S.P. Physiologic hypoxia and oxygen homeostasis in the healthy intestine. A Review in the Theme: Cellular Responses to Hypoxia. Am. J. Physiol. Cell Physiol. 2015, 309, C350-C360. [CrossRef]

41. Semenza, G.L. Oxygen Sensing, Homeostasis, and Disease. N. Engl. J. Med. 2011, 365, 537-547. [CrossRef] [PubMed]

42. Bartrons, R.; Caro, J. Hypoxia, glucose metabolism and the Warburg's effect. J. Bioenerg. Biomembr. 2007, 39, 223-229. [CrossRef] [PubMed]

43. Jin, L.; Alesi, G.N.; Kang, S. Glutaminolysis as a target for cancer therapy. Oncogene 2016, 35, 3619-3625. [CrossRef]

44. Matés, J.M.; Di Paola, F.J.; Campos-Sandoval, J.A.; Mazurek, S.; Márquez, J. Therapeutic targeting of glutaminolysis as an essential strategy to combat cancer. Semin. Cell Dev. Biol. 2020, 98, 34-43. [CrossRef] [PubMed]

45. Unterluggauer, H.; Mazurek, S.; Lener, B.; Hütter, E.; Eigenbrodt, E.; Zwerschke, W.; Jansen-Dürr, P. Premature senescence of human endothelial cells induced by inhibition of glutaminase. Biogerontology 2008, 9, 247-259. [CrossRef] 
46. Papandreou, I.; Cairns, R.A.; Fontana, L.; Lim, A.L.; Denko, N.C. HIF-1 mediates adaptation to hypoxia by actively downregulating mitochondrial oxygen consumption. Cell Metab. 2006, 3, 187-197. [CrossRef]

47. Shahiduzzaman, M.; Dyachenko, V.; Obwaller, A.; Unglaube, S.; Daugschies, A. Combination of cell culture and quantitative PCR for screening of drugs against Cryptosporidium parvum. Vet. Parasitol. 2009, 162, 271-277. [CrossRef]

48. Holzhausen, I.; Lendner, M.; Göhring, F.; Steinhöfel, I.; Daugschies, A. Distribution of Cryptosporidium parvum gp60 subtypes in calf herds of Saxony, Germany. Parasitol. Res. 2019, 118, 1549-1558. [CrossRef]

49. Vélez, J.; Lange, M.K.; Zieger, P.; Yoon, I.; Failing, K.; Bauer, C. Long-term use of yeast fermentation products in comparison to halofuginone for the control of cryptosporidiosis in neonatal calves. Vet. Parasitol. 2019, 269, 57-64. [CrossRef]

50. Broglia, A.; Reckinger, S.; Cacció, S.M.; Nöckler, K. Distribution of Cryptosporidium parvum subtypes in calves in Germany. Vet. Parasitol. 2008, 154, 8-13. [CrossRef]

51. Nichols, G.L.; Chalmers, R.M.; Hadfield, S.J. Molecular Epidemiology of Human Cryptosporidiosis. In Cryptosporidium: Parasite and Disease; Cacciò, S.M., Widmer, G., Eds.; Springer: Vienna, Austria, 2014; pp. 81-147.

52. Varughese, E.A.; Bennett-Stamper, C.L.; Wymer, L.J.; Yadav, J.S. A new in vitro model using small intestinal epithelial cells to enhance infection of Cryptosporidium parvum. J. Microbiol. Methods 2014, 106, 47-54. [CrossRef] [PubMed]

53. Fichtner, T.; Kotarski, F.; Gärtner, U.; Conejeros, I.; Hermosilla, C.; Wrenzycki, C.; Taubert, A. Bovine sperm samples induce different NET phenotypes in a NADPH oxidase-, PAD4-, and Ca++-dependent process. Biol. Reprod. 2020, 102, 902-914. [CrossRef] [PubMed]

54. Eigenbrodt, E.; Kallinowski, F.; Ott, M.; Mazurek, S.; Vaupel, P. Pyruvate kinase and the interaction of amino acid and carbohydrate metabolism in solid tumors. Anticancer Res. 1998, 18, 3267-3274. [PubMed]

55. Mazurek, S.; Eigenbrodt, E.; Failing, K.; Steinberg, P. Alterations in the glycolytic and glutaminolytic pathways after malignant transformation of rat liver oval cells. J. Cell. Physiol. 1999, 181, 136-146. [CrossRef]

56. Mazurek, S.; Zwerschke, W.; Jansen-Dürr, P.; Eigenbrodt, E. Effects of the human papilloma virus HPV-16 E7 oncoprotein on glycolysis and glutaminolysis: Role of pyruvate kinase type M2 and the glycolytic-enzyme complex. Biochem. J. 2001, 356, 247-256. [CrossRef] [PubMed]

57. Ammon, H.P.T. Methoden der Enzymatischen Analyse; Von, H.U., Ed.; Verlag Chemie GmbH: Weinheim/Bergstraße, Germany, 1974; pp. 92-93.

58. Divakaruni, A.S.; Paradyse, A.; Ferrick, D.A.; Murphy, A.N.; Jastroch, M. Analysis and interpretation of microplate-based oxygen consumption and pH data. Methods Enzymol. 2014, 547, 309-354. [CrossRef]

59. Medina, M.A.; Ignacio, N.; Castro, D. Glutaminolysis and glycolysis interactions in proliferant cells. Int. J. Biochem. 1990, 22, 681-683. [CrossRef]

60. Jacot, D.; Waller, R.F.; Soldati-Favre, D.; MacPherson, D.A.; MacRae, J.I. Apicomplexan Energy Metabolism: Carbon Source Promiscuity and the Quiescence Hyperbole. Trends Parasitol. 2016, 32, 56-70. [CrossRef]

61. Bhattacharya, B.; Omar, M.F.M.; Soong, R. The Warburg effect and drug resistance. Br. J. Pharmacol. 2016, 173, 970-979. [CrossRef]

62. Dixon, W.J. BMDP Statistical Software Manual: To Accompany BMDP/Dynamic Release 8.1; University of California Press: Berkeley, CA, USA, 1993; Volume 1-2.

63. Farabegoli, F.; Vettraino, M.; Manerba, M.; Fiume, L.; Roberti, M.; Di Stefano, G. Galloflavin, a new lactate dehydrogenase inhibitor, induces the death of human breast cancer cells with different glycolytic attitude by affecting distinct signaling pathways. Eur. J. Pharm. Sci. 2012, 47, 729-738. [CrossRef]

64. Penna-Coutinho, J.; Cortopassi, W.A.; Oliveira, A.A.; França, T.C.C.; Krettli, A.U. Antimalarial Activity of Potential Inhibitors of Plasmodium falciparum Lactate Dehydrogenase Enzyme Selected by Docking Studies. PLoS ONE 2011, 6, e21237. [CrossRef]

65. Nath, K.; Guo, L.; Nancolas, B.; Nelson, D.S.; Shestov, A.A.; Lee, S.-C.; Roman, J.; Zhou, R.; Leeper, D.B.; Halestrap, A.P.; et al. Mechanism of antineoplastic activity of lonidamine. Biochim. Biophys. Rev. Cancer 2016, 1866, 151-162. [CrossRef]

66. Guo, L.; Shestov, A.A.; Worth, A.J.; Nath, K.; Nelson, D.S.; Leeper, D.B.; Glickson, J.D.; Blair, I.A. Inhibition of Mitochondrial Complex II by the Anticancer Agent Lonidamine. J. Biol. Chem. 2016, 291, 42-57. [CrossRef] [PubMed]

67. Benjamin, D.; Robay, D.; Hindupur, S.K.; Pohlmann, J.; Colombi, M.; El-Shemerly, M.Y.; Maira, S.-M.; Moroni, C.; Lane, H.A.; Hall, M.N. Dual Inhibition of the Lactate Transporters MCT1 and MCT4 Is Synthetic Lethal with Metformin due to NAD+ Depletion in Cancer Cells. Cell Rep. 2018, 25, 3047-3058. [CrossRef] [PubMed]

68. Benjamin, D.; Colombi, M.; Hindupur, S.K.; Betz, C.; Lane, H.A.; El-Shemerly, M.Y.M.; Lu, M.; Quagliata, L.; Terracciano, L.; Moes, S.; et al. Syrosingopine sensitizes cancer cells to killing by metformin. Sci. Adv. 2016, 2, e1601756. [CrossRef]

69. Lu, W.; Pelicano, H.; Huang, P. Cancer metabolism: Is glutamine sweeter than glucose? Cancer Cell 2010, 18, 199-200. [CrossRef]

70. Leander, B.S.; Lloyd, S.A.J.; Marshall, W.; Landers, S.C. Phylogeny of Marine Gregarines (Apicomplexa)—Pterospora, Lithocystis and Lankesteria — and the Origin(s) of Coelomic Parasitism. Protist 2006, 157, 45-60. [CrossRef]

71. Cavalier-Smith, T.; Chao, E.E. Protalveolate phylogeny and systematics and the origins of Sporozoa and dinoflagellates (phylum Myzozoa nom. nov.). Eur. J. Protistol. 2004, 40, 185-212. [CrossRef]

72. Gentile, A.; Sconza, S.; Lorenz, I.; Otranto, G.; Rademacher, G.; Famigli-Bergamini, P.; Klee, W. d-Lactic Acidosis in Calves as a Consequence of Experimentally Induced Ruminal Acidosis. J. Vet. Med. 2004, 51, 64-70. [CrossRef]

73. Lorenz, I.; Gentile, A. d-Lactic Acidosis in Neonatal Ruminants. Vet. Clin. Food Anim. Pract. 2014, 30, 317-331. [CrossRef]

74. Boza, J.J.; Moënnoz, D.; Bournot, C.E.; Blum, S.; Zbinden, I.; Finot, P.A.; Ballèvre, O. Role of glutamine on the de novo purine nucleotide synthesis in Caco-2 cells. Eur. J. Nutr. 2000, 39, 38-46. [CrossRef] [PubMed] 
75. Mazurek, S.; Boschek, C.B.; Hugo, F.; Eigenbrodt, E. Pyruvate kinase type M2 and its role in tumor growth and spreading. Semin. Cancer Biol. 2005, 15, 300-308. [CrossRef] [PubMed]

76. Zielke, H.R.; Sumbilla, C.M.; Sevdalian, D.A.; Hawkins, R.L.; Ozand, P.T. Lactate: A major product of glutamine metabolism by human diploid fibroblasts. J. Cell. Physiol. 1980, 104, 433-441. [CrossRef] [PubMed]

77. Zielke, H.R.; Ozand, P.T.; Tildon, J.T.; Sevdalian, D.A.; Cornblath, M. Reciprocal regulation of glucose and glutamine utilization by cultured human diploid fibroblasts. J. Cell. Physiol. 1978, 95, 41-48. [CrossRef] [PubMed]

78. Ardawi, M.S.M. Glutamine and glucose metabolism in human peripheral lymphocytes. Metabolism 1988, 37, 99-103. [CrossRef]

79. Wu, G. Intestinal Mucosal Amino Acid Catabolism. J. Nutr. 1998, 128, 1249-1252. [CrossRef]

80. Rhoads, J.M.; Argenzio, R.A.; Chen, W.; Rippe, R.A.; Westwick, J.K.; Cox, A.D.; Berschneider, H.M.; Brenner, D.A. L-glutamine stimulates intestinal cell proliferation and activates mitogen-activated protein kinases. Am. J. Physiol. Gastroint. Liver Physiol. 1997, 272, G943-G953. [CrossRef]

81. Scheppach, W.; Loges, C.; Bartram, P.; Christl, S.U.; Richter, F.; Dusel, G.; Stehle, P.; Fuerst, P.; Kasper, H. Effect of free glutamine and alanyl-glutamine dipeptide on mucosal proliferation of the human ileum and colon. Gastroenterology 1994, 107, 429-434. [CrossRef]

82. Li, N.; Lewis, P.; Samuelson, D.; Liboni, K.; Neu, J. Glutamine regulates Caco-2 cell tight junction proteins. Am. J. Physiol. Gastroint. Liver Physiol. 2004, 287, G726-G733. [CrossRef]

83. DeMarco, V.G.; Li, N.; Thomas, J.; West, C.M.; Neu, J. Glutamine and Barrier Function in Cultured Caco-2 Epithelial Cell Monolayers. J. Nutr. 2003, 133, 2176-2179. [CrossRef]

84. Alverdy, J.C. Effects of Glutamine-Supplemented Diets on Immunology of the Gut. J. Parenter. Enter. Nutr. 1990, 14, 109S-113S. [CrossRef]

85. Li, P.; Yin, Y.-L.; Li, D.; Kim, S.W.; Wu, G. Amino acids and immune function. Br. J. Nutr. 2007, 98, 237-252. [CrossRef]

86. Lima, A.A.M.; Brito, L.F.B.; Ribeiro, H.B.; Martins, M.C.V.; Lustosa, A.P.; Rocha, E.M.; Lima, N.L.; Monte, C.M.G.; Guerrant, R.L. Intestinal Barrier Function and Weight Gain in Malnourished Children Taking Glutamine Supplemented Enteral Formula. J. Pediatr. Gastroenterol. Nutr. 2005, 40, 28-35. [CrossRef] [PubMed]

87. Alarcón, P.; Manosalva, C.; Conejeros, I.; Carretta, M.D.; Muñoz-Caro, T.; Silva, L.M.R.; Taubert, A.; Hermosilla, C.; Hidalgo, M.A.; Burgos, R.A. d(-) Lactic Acid-Induced Adhesion of Bovine Neutrophils onto Endothelial Cells Is Dependent on Neutrophils Extracellular Traps Formation and CD11b Expression. Front. Immunol. 2017, 8, 975. [CrossRef] [PubMed]

88. Hidalgo, A.I.; Carretta, M.D.; Alarcón, P.; Manosalva, C.; Müller, A.; Navarro, M.; Hidalgo, M.A.; Kaehne, T.; Taubert, A.; Hermosilla, C.R.; et al. Pro-inflammatory mediators and neutrophils are increased in synovial fluid from heifers with acute ruminal acidosis. BMC Vet. Res. 2019, 15, 225. [CrossRef] [PubMed]

89. Brinkmann, V.; Zychlinsky, A. Neutrophil extracellular traps: Is immunity the second function of chromatin? J. Cell Biol. 2012, 198, 773-783. [CrossRef]

90. Hermosilla, C.; Caro, T.M.; Silva, L.M.R.; Ruiz, A.; Taubert, A. The intriguing host innate immune response: Novel anti-parasitic defence by neutrophil extracellular traps. Parasitology 2014, 141, 1489-1498. [CrossRef]

91. Muñoz-Caro, T.; Lendner, M.; Daugschies, A.; Hermosilla, C.; Taubert, A. NADPH oxidase, MPO, NE, ERK1/2, p38 MAPK and Ca2+ influx are essential for Cryptosporidium parvum-induced NET formation. Dev. Comp. Immunol. 2015, 52, 245-254. [CrossRef]

92. dos Santos, R.D.G.C.; Viana, M.L.; Generoso, S.V.; Arantes, R.E.; Davisson Correia, M.I.T.; Cardoso, V.N. Glutamine Supplementation Decreases Intestinal Permeability and Preserves Gut Mucosa Integrity in an Experimental Mouse Model. J. Parenter. Enter. Nutr. 2010, 34, 408-413. [CrossRef]

93. De-Souza, D.A.; Greene, L.J. Intestinal permeability and systemic infections in critically ill patients: Effect of glutamine. Crit. Care Med. 2005, 33, 1125-1135. [CrossRef]

94. Conejero, R.; Bonet, A.; Grau, T.; Esteban, A.; Mesejo, A.; Montejo, J.C.; López, J.; Acosta, J.A. Effect of a glutamine-enriched enteral diet on intestinal permeability and infectious morbidity at 28 days in critically ill patients with Systemic Inflammatory Response Syndrome: A randomized, single-blind, prospective, multicenter study. Nutrition 2002, 18, 716-721. [CrossRef]

95. Gao, P.; Tchernyshyov, I.; Chang, T.-C.; Lee, Y.-S.; Kita, K.; Ochi, T.; Zeller, K.I.; De Marzo, A.M.; Van Eyk, J.E.; Mendell, J.T.; et al. c-Myc suppression of miR-23a/b enhances mitochondrial glutaminase expression and glutamine metabolism. Nature 2009, 458, 762-765. [CrossRef] [PubMed]

96. Wang, J.-B.; Erickson, J.W.; Fuji, R.; Ramachandran, S.; Gao, P.; Dinavahi, R.; Wilson, K.F.; Ambrosio, A.L.B.; Dias, S.M.G.; Dang, C.V.; et al. Targeting mitochondrial glutaminase activity inhibits oncogenic transformation. Cancer Cell 2010, 18, 207-219. [CrossRef] [PubMed]

97. Weiser, M.M. Intestinal Epithelial Cell Surface Membrane Glycoprotein Synthesis I. An indicator of cellular differentiation. J. Biol. Chem. 1973, 248, 2536-2541. [CrossRef]

98. Eigenbrodt, E.; Glossmann, H. Glycolysis—one of the keys to cancer? Trends Pharmacol. Sci. 1980, 1, 240-245. [CrossRef]

99. Yang, Z.; Wei, Z.; Hermosilla, C.; Taubert, A.; He, X.; Wang, X.; Gong, P.; Li, J.; Zhang, X. Caprine monocytes release extracellular traps against Neospora caninum in vitro. Front. Immunol. 2018, 8, 2016. [CrossRef]

100. Peixoto, R.; Silva, L.M.; López-Osório, S.; Zhou, E.; Gärtner, U.; Conejeros, I.; Taubert, A.; Hermosilla, C. Fasciola hepatica induces weak NETosis and low production of intra- and extracellular ROS in exposed bovine polymorphonuclear neutrophils. Dev. Comp. Immunol. 2020, 114, 103787. [CrossRef] 
101. Pinheiro, C.; Longatto-Filho, A.; Azevedo-Silva, J.; Casal, M.; Schmitt, F.C.; Baltazar, F. Role of monocarboxylate transporters in human cancers: State of the art. J. Bioenerg. Biomembr. 2012, 44, 127-139. [CrossRef]

102. Park, Y.; Diez-Silva, M.; Popescu, G.; Lykotrafitis, G.; Choi, W.; Feld, M.S.; Suresh, S. Refractive index maps and membrane dynamics of human red blood cells parasitized by Plasmodium falciparum. Proc. Natl. Acad. Sci. USA 2008, 105, 13730-13735. [CrossRef]

103. Charrière, F.; Pavillon, N.; Colomb, T.; Depeursinge, C.; Heger, T.J.; Mitchell, E.A.D.; Marquet, P.; Rappaz, B. Living specimen tomography by digital holographic microscopy: Morphometry of testate amoeba. Opt. Express 2006, 14, 7005-7013. [CrossRef]

104. Yakimovich, A.; Witte, R.; Andriasyan, V.; Georgi, F.; Greber, U.F. Label-Free Digital Holo-tomographic Microscopy Reveals Virus-Induced Cytopathic Effects in Live Cells. MSphere 2018, 3, e00599-18. [CrossRef] [PubMed] 